Boston University School of Law

Scholarly Commons at Boston University School of Law

Faculty Scholarship

2007

\title{
Physicians' Insurance Limits and Malpractice Payments: Evidence from Texas Closed Claims, 1990-2003
}

\author{
Kathryn Zeiler \\ Boston University School of Law \\ Charles Silver \\ Bernard Black \\ David Hyman \\ William Sage
}

Follow this and additional works at: https://scholarship.law.bu.edu/faculty_scholarship

Part of the Insurance Law Commons, and the Medical Jurisprudence Commons

\section{Recommended Citation}

Kathryn Zeiler, Charles Silver, Bernard Black, David Hyman \& William Sage, Physicians' Insurance Limits and Malpractice Payments: Evidence from Texas Closed Claims, 1990-2003, 36 Journal of Legal Studies 59 (2007).

Available at: https://scholarship.law.bu.edu/faculty_scholarship/718

This Article is brought to you for free and open access by Scholarly Commons at Boston University School of Law. It has been accepted for inclusion in Faculty Scholarship by an authorized administrator of Scholarly Commons at Boston University School of Law. For more information, please contact lawlessa@bu.edu. 
New York University School of Law

NYU Law and Economics Research Paper No. 07-16

University of Illinois College of Law

U Illinois Law \& Economics Research Paper No. LE07-008

University of Texas School of Law

$\mathrm{U}$ of Texas Law, Law and Econ Research Paper No. 67

Georgetown University Law Center

Georgetown Law and Economics Research Paper No. 981192

Journal of Legal Studies, Forthcoming

\title{
Physicians' Insurance Limits and Malpractice Payments: Evidence from Texas Closed Claims, 1990-2003
}

KATHRYN ZEILER

Georgetown University Law Center; New York University - School of Law

CHARLES SILVER

University of Texas at Austin

\section{BERNARD S. BLACK}

University of Texas at Austin - School of Law; McCombs School of Business, University of Texas at Austin; European Corporate Governance Institute (ECGI)

\author{
DAVID A. HYMAN \\ University of Illinois College of Law \\ WILLIAM M. SAGE \\ University of Texas at Austin
}

This paper can be downloaded without charge from the Social Science Research Network Electronic Paper Collection at: http://ssrn.com/abstract $=981192$ 


\title{
Physicians' Insurance Limits and Malpractice Payments: Evidence from Texas Closed Claims, 1990-2003
}

\author{
Kathryn Zeiler, ${ }^{*}$ \\ Charles Silver, \\ Bernard Black, ${ }^{* * * * * *}$ \\ David A. Hyman, \\ William M. Sage,
}

(forthcoming, Journal of Legal Studies)

\footnotetext{
* Visiting Professor of Law, New York University School of Law; Professor of Law, Georgetown University Law Center, zeiler@law.georgetown.edu. We thank Jennifer Arlen, Ronen Avraham, Tom Baker, Russell Localio, Steve Salop, Steve Shavell and an anonymous referee for helpful comments and suggestions. We also benefited from workshops presented at the American Law and Economics Association Annual Meeting and law schools at Brooklyn University, University of Chicago, Duke, Georgetown, Harvard, NYU and the University of Illinois, and the University of Virginia. JaeJoon Han and An-Shih Liu provided excellent research assistance. Grants from the University of Texas at Austin School of Law, the University of Illinois College Of Law, Columbia Law School, and the Georgetown University Law Center supported this research.

${ }^{* *}$ McDonald Endowed Chair in Civil Procedure, University of Texas Law School

${ }^{* * *}$ Hayden W. Head Regents Chair for Faculty Excellence, University of Texas Law School, and Professor of Finance, University of Texas, Red McCombs School of Business

${ }^{* * * *}$ Professor of Law and Medicine, University of Illinois

${ }^{* * * * *}$ James R. Dougherty Chair for Faculty Excellence in Law, University of Texas School of Law, and Vice-Provost for Health Affairs, University of Texas at Austin
} 


\begin{abstract}
Physicians' insuring practices influence their incentives to take care when treating patients, their risk of making out-of-pocket payments in malpractice cases, and the adequacy of compensation available to injured patients. Yet, these practices and their effects have rarely been studied. Using Texas Department of Insurance data on 9,525 paid malpractice claims against physicians that closed 1990-2003, we provide the first systematic evidence on levels of coverage purchased by physicians with paid liability claims and how those levels affect out-of-pocket payments and patient compensation. We find that these physicians carried much less insurance than is conventionally believed, that their real primary limits declined steadily over time, that policy limits often act as effective caps on recovery, and that personal contributions by physicians to close claims were rare. Our findings call into question a number of common assumptions about the relationship between physician insuring practices and the medical malpractice liability system.
\end{abstract}




\title{
Physicians' Insurance Limits and Malpractice Payments: Evidence from Texas Closed Claims, 1990-2003
}

\author{
Kathryn Zeiler, Charles Silver, Bernard Black, David A. Hyman, William M. Sage
}

\section{INTRODUCTION}

Malpractice insurance influences many effects of the tort system, including physicians' incentives to provide non-negligent care, their risk of having to use personal assets to resolve claims, and the amount of compensation available to cover patients' losses.. Unfortunately, little is known about physicians' insuring practices. Few studies examine the size of their malpractice policies or changes in their insurance purchasing habits over time. ${ }^{1}$ The connections between the size of doctors' policies, payments in medical malpractice cases, and physicians' personal exposure on malpractice claims have also been ignored. A dearth of reliable data has prevented study of these matters.

Using data on 9,525 malpractice claims that closed with payments from 1990 to 2003 collected by the Texas Department of Insurance (TDI), this study finds, first, that Texas physicians with paid claims carried much less insurance than is conventionally believed. ${ }^{2}$ Physicians who faced perinatal claims, which tend to be larger than other claims, purchased policies with lower limits than other physicians. We also find for both perinatal physicians and other physicians that real policy size declined significantly over time, while nominal policy size remained stable.

\footnotetext{
${ }^{1}$ Anecdotal reports indicate that policy size varies across states, specialties, time, and in reaction to premiums (see General Accounting Office (2003a)). Existing studies of policy size focus on dentists or anesthesiologists rely on surveys of physicians that contain little or no data on policy size, or cover short time spans. See e.g., Milgrom et al. (1995); Conrad et al. (1995); Milgrom et al. (1994); O'Hara et al. (1994); and Lawthers et al. (1992).

${ }^{2}$ The conventional wisdom is that most physicians carry policies with $\$ 1$ million per-occurrence limits. See e.g., Cheney (1999); Quinn (1998); and American College of Emergency Physicians (2004).
} 
Second, this study finds that, in the vast majority of cases, policy limits act as de facto caps on payments: $98.5 \%(9,238 / 9.389)$ of claims were resolved with payments at or below primary malpractice policy limits. A sharp spike in payments at or near the policy limits punctuates their importance: approximately $16 \%(1,465 / 9,389)$ of claims were resolved with payments between 95 and 100 percent of the limits; most of these payments were exactly at the limits. The size of the at-limits spike increases as policy size falls. In the case of perinatal physicians, the spike was exceptionally large, reflecting their tendency to face claims with large dollar exposure and to maintain lower coverage.

Third, this study finds that physicians rarely used personal assets to resolve malpractice claims. ${ }^{3}$ Only about $1.5 \%$ of claims had above-limit payments, and primary carriers funded most of these. Overall, primary carriers resolved $99.4 \%$ of paid claims using only their money and provided $98.8 \%$ of the total dollars claimants received. From 1990 to 2003, the TDI dataset reports 62 out-of-pocket payments by physicians, an average of 4 per year, 10 of which exceeded $\$ 300,000(2003 \$) .{ }^{4}$ Out-of-pocket payments are infrequent even though many physicians purchase policies that are well below mean and median jury awards. ${ }^{5}$ Doctors with policies under $\$ 250,000$ (\$2003) paid out-ofpocket more often than others, but the probability of a doctor with a policy this small making an out-of-pocket payment was still low.

Because policy limits seem to effectively cap most recoveries, the trend toward smaller real policies may affect claim rates and payments to claimants. We find that per-

\footnotetext{
${ }^{3}$ For discussions of insured physicians' perceived personal exposure, see Brennan and Mello (2003) (describing a case study in which a physician worried about awards in excess of his coverage and a subsequent need to file for bankruptcy); Lowes (2003); Rice (2003); American Medical Association, Liability Insurance Requirements, http://www.ama-assn.org/ama/pub/category/4544.html; and Jenkins (2003).

${ }^{4}$ By "out-of-pocket payment" we mean payments made by physicians above the amounts paid by primary insurers but not including deductible payments.

${ }^{5}$ On jury awards in medical malpractice cases, see Hyman et al. (2007).
} 
claim payments on claims involving perinatal injuries fell over our study period, while payments on other claims were roughly stable. ${ }^{6}$ We lack sufficient data to estimate what payments would have been had real policy sizes not declined over time.

This article proceeds as follows. Part II describes the data, provides summary statistics and details limitations of the study. Part III provides results related to the relationship between policy limits and recoveries, the allocation of payments between physicians and insurers, changes in coverage over time, and changes over time in payments to claimants. ${ }^{7}$ Part IV discusses the results, and Part V concludes.

\section{THE DATA AND THE LEGAL ENVIRONMENT}

\subsection{The Texas Closed Claims Database}

Texas is the country's second most populous state. It spends the third largest amount on health care (National Health Expenditure Data (2006)). It has a large and growing physician population (Texas Department of Health (2003) and a highly developed trial bar (Daniels and Martin (2002). It was especially hard-hit by rising medical malpractice insurance premiums during the recent malpractice "crisis" (Texas Department of Insurance (2003). Texas enacted sweeping tort reform legislation in $2003 .{ }^{8}$ During the period relevant to this study (1988-2003), it enacted more limited reforms, described in Part 2.3.

\footnotetext{
${ }^{6}$ In prior work, we found stable mean (median) payments by all defendants in large paid Texas medical malpractice claims form 1988-2002, but did not separately study claims against physicians. See Black et al. (2005).

${ }^{7}$ We also examined trends in deductibles and payments by excess insurers. The results relating to these subjects are available on request.

${ }^{8}$ Act of June 2, 2003, 78th Leg., Reg. Sess., ch. 204, 2003 Tex. Gen. Laws 847.
} 
Texas also maintains the Texas Closed Claim Database (TCCD). ${ }^{9}$ Since 1988, the Texas Department of Insurance (TDI) has required commercial insurers ${ }^{10}$ to file three types of reports on closed malpractice claims: brief aggregate reports of claims with total payments by all defendants of $\$ 0-\$ 10,000$; "Short Form" individual reports of claims with payments by all defendants of \$10,001-\$24,999; and more detailed, "Long Form" reports on claims with payments by all defendants of $\$ 25,000$ and up (all in nominal dollars). The reporting format remained substantially unchanged during the entire period, facilitating comparisons over time. A recent work describes the TCCD more fully (Black et al. (2005, pp. 213-22)).

TDI has audited the information relating to primary carriers' payments for accuracy since 1990, and it returns incomplete reports. Although TDI does not audit other reported information, primary carriers have direct access to all unaudited information used in this study, including amounts paid by physicians and excess insurers, because they handle negotiations and must obtain consent from others before committing their funds. A comparison between reported data and insurers' file would completely allay all accuracy concerns, but we have not made this comparison. We rely here on reports from

\footnotetext{
9 The annual closed claim surveys containing the data files are available at http://www.tdi.state.tx.us/reports/report4.html.

${ }^{10}$ According to the Closed Claim Reporting Guide: "Each insurance company or other entity admitted to do business and authorized to write liability insurance in Texas, including county mutual insurance companies, Lloyd's plan companies, and reciprocal or inter-insurance exchanges, ... and each pool, joint underwriting association, or self-insurance mechanism or trust authorized by law to insure its participants, subscribers, or members against liability must submit quarterly closed claim report forms."

Most physicians carry malpractice insurance, but many hospitals do not. We lack data on claims against the University of Texas hospital system and on claims against UT-employed physicians. The UT hospital system is self-insured, and UT-employed physicians are insured by the UT System. Thus, our data likely capture most cases in which physicians make payments, but a smaller and unknown fraction in which the payers are hospitals and other providers. TDI estimated that in 2005 reporting entities covered $75 \%$ of licensed practicing Texas physicians (conversations with TDI).
} 
1990-2003 (2003 was the last available year when we collected the data for this project). ${ }^{11}$

"Short-form" reports of claims with total payments of $\$ 10,001$ or more identify the nature of the policyholder and the type of insurance coverage; "long-form" reports with total payments of $\$ 25,000$ or more also identify the cause of injury. This study uses only claims in which (1) the policyholder was a physician, (2) a medical malpractice policy provided coverage, and (3) the cause of injury was "complications, misadventures of surgical/medical care" (this requirement limits us to using only long-form reports). Using the language set out in Black et al. (2005) this dataset is the NAR (for "narrow") dataset limited to physicians. We do not study hospitals, nursing homes, or other health care providers, whose insuring habits, litigation practices, and claim outcomes might differ from physicians'. The second and third constraints limit the dataset to claims that would conventionally be considered to involve medical malpractice. Some Long Form reports contain information about payments below $\$ 25,000$ (nominal) by individual physicians. The dataset includes these reports.

TDI has never adjusted the $\$ 25,000$ reporting threshold for inflation. Counting claims above the reporting threshold without adjusting for inflation would convey misleading information about claim frequencies and payment amounts. We address this problem of "bracket creep" by considering only reports with total payments of $\$ 25,000$ or

\footnotetext{
${ }^{11}$ In other studies (e.g., Black et al. (2005), Hyman et al. (2007), Black et al. (2007)), we also use reports of claims that closed in 1988 and 1989. Some have criticized our use of these years because TDI did not audit these reports and because there was apparently some amount of non-compliance (under-reporting). Using a variety of statistical tests, we find no evidence that the reports available for these years are biased, relative to reports available from 1990 on. We therefore believe the 1988-1989 data are reliable except for analyses that require complete reporting (e.g., counts). We chose not to use the 1988-1989 reports in this study to avoid possible criticism based on incompleteness of the data or bias in reporting. Our main results are robust to analyses including these years
} 
more measured in 1988 dollars. ${ }^{12}$ This adjustment eliminated 572 claims, 6\% of the claims but only $1 \%$ of dollars paid. The final sample size is 9,525 insured payments on 8,400 distinct claims, closed 1990-2003 with payouts over \$25,000 in 1988 dollars ("large paid claims"). We report our findings in 2003 dollars.

To determine the total payment for a particular physician, we summed the deductible payment, the primary carrier's payment, the excess carrier's payment, and the physician's payment above the primary policy limit. ${ }^{13}$ The dataset contains reports for each insured defendant when payments were made on behalf of multiple defendants. We refer to these related observations as "duplicates." 14 We include all reports when analyzing policy limits and payments. We exclude duplicate reports when discussing trial verdicts.

Although the dataset includes claims on policies sold as early as 1965 , when analyzing policy limits we can reasonably rely only on policies purchased from 1988 through 1999. For example, all claims in the dataset relating to policies purchased in 2003 were closed in 2003, and these claims might be an unrepresentative subset of the entire group of claims that eventually will close under policies purchased in this years. For example, larger claims may take longer to resolve than smaller ones. ${ }^{15}$ In addition, real total payments are positively correlated with real limits $(r=0.22)$. Therefore, claims that close relatively quickly might have smaller limits. Our examination of the data indicates that our sample is reasonably complete for policies purchased 1988-1999, but

\footnotetext{
${ }^{12} \$ 25,000$ in 1988 has the same buying power as $\$ 38,884$ in 2003 .

${ }^{13}$ While TDI does not audit reports of payments by excess carriers and physicians, insurers have easy access to these amounts given that final settlements typically are negotiated for all sources of payment on behalf of a single defendant. We have no reason to believe that this information is inaccurate or incomplete.

${ }^{14}$ With regard to our procedures for identifying duplicate reports, see Hyman et al. (2007).

${ }^{15}$ See Silver (2002) (summarizing studies and concluding that "[p]arties investigate more thoroughly and otherwise spend more time when claims are large and complicated than when they are small and straightforward"). But see, Black et al. (2007).
} 
not earlier or later. When studying policy size, we therefore limit the dataset to closed claims covered by policies purchased during these years.

Malpractice policies typically contain both "per occurrence" limits and aggregate annual limits. TDI requires insurers to report the "per occurrence" limit. We used this to measure policy size when available (8,657 claims). Instead of reporting a "per occurrence" limit, carriers sometimes reported a "combined single limit."16 We used this to measure policy size for 868 claims for which "per occurrence" limits were not reported. We obtained results similar to those reported below when we limited our analyses to claims with reported "per occurrence" limits. When studying limits and their effect on payments, we exclude 136 claims with payments by excess carriers because we lack information on excess policy size.

Some policies are "claims-made" and cover claims made during a coverage year; others are "occurrence" and cover claims for harm stemming from services rendered during a coverage year, no matter when the claims arise. The TDI data reports policy type but not the year the policy was purchased. We set the purchase year as the year a claim was reported for claims-made policies $(5,911$ claims) and as the year an injury occurred for occurrence polices $(3,614$ claims). In robustness checks on relationships between payments and limits and on purchasing trends, we analyzed occurrence policies and claims-made policies separately. No significant differences emerged.

When performing our analyses, we use data from several non-TCCD sources. The table in the Appendix identifies the sources and the variables drawn from them, and indicates how the variables enter into our analyses.

\footnotetext{
${ }^{16}$ Liability policies usually offer separate limits that apply to bodily injury claims and to claims for other types of damages. A combined single limit policy covers all damages per occurrence regardless of injury type.
} 


\subsection{Summary Statistics}

Table 1 presents summary statistics. Smaller paid claims greatly outnumber larger paid claims, but the larger claims are disproportionately important. Eighty-five percent of the claims had payments of $\$ 500,000$ or less (in 2003 dollars), but the $15 \%$ of claims with payments exceeding $\$ 500,000$ accounted for $48 \%$ of total payments. Table 2 provides additional summary statistics by closing year on general indices, payments on liability claims, and policy limits covering closed claims.

Table 1: Summary Statistics

\begin{tabular}{ccccc}
\hline $\begin{array}{c}\text { Payment Range } \\
\text { (in 2003\$) }\end{array}$ & $\begin{array}{c}\text { Number of } \\
\text { Closed } \\
\text { Claims }\end{array}$ & $\begin{array}{c}\text { \%of of } \\
\text { Total }\end{array}$ & $\begin{array}{c}\text { Total Payments } \\
\text { (in millions of }\end{array}$ & $\begin{array}{c}\mathbf{2 0 0 3 \$} \text { ) } \\
\text { of } \\
\text { Total } \\
\$ 1-100,000\end{array}$ \\
2,968 & $31 \%$ & $\$ 178$ & $7 \%$ \\
$\$ 100,001-500,000$ & 5,184 & $54 \%$ & $\$ 1,163$ & $45 \%$ \\
$\$ 500,001-1,000,000$ & 1,021 & $11 \%$ & $\$ 686$ & $27 \%$ \\
Over $\$ 1,000,000$ & 352 & $4 \%$ & $\$ 542$ & $21 \%$ \\
Total & $\mathbf{9 , 5 2 5}$ & $\mathbf{1 0 0 \%}$ & $\mathbf{\$ 2 , 5 6 9}$ & $\mathbf{1 0 0 \%}$ \\
\hline
\end{tabular}

Note: Number of closed claims and total payments related to all claims against physicians included in the NAR data set of medical malpractice claims closed from 1990-2003 with a payout greater than $\$ 25,000$ in 1988 dollars (including duplicates). "Total Payments" is the sum of all payments made by or on behalf of the insured physician, excluding amounts reported as having been made by other defendants or their insurers. 
Table 2: Additional Summary Statistics by Closing Year (2003\$)

\begin{tabular}{|c|c|c|c|}
\hline $\begin{array}{c}\text { Statistics on General } \\
\text { Health Care }\end{array}$ & Payments on Liability Claims Against Physicians & Payment per Large Paid Claim \\
& & \\
\hline
\end{tabular}

\begin{tabular}{|c|c|c|c|c|c|c|c|c|c|c|c|c|}
\hline $\begin{array}{l}\text { Claim } \\
\text { closing } \\
\text { year }\end{array}$ & $\begin{array}{c}\text { Practicing } \\
\text { TX } \\
\text { physicians }\end{array}$ & $\begin{array}{c}\text { Health care } \\
\text { expenditures } \\
\text { for all TX } \\
\text { payors (in } \\
\text { millions) }\end{array}$ & $\begin{array}{c}\text { Number of } \\
\text { paid } \\
\text { claims }\end{array}$ & $\begin{array}{l}\text { Paid claims } \\
\text { per } 100 \\
\text { practicing TX } \\
\text { physicians } 1,2\end{array}$ & $\begin{array}{c}\text { Total } \\
\text { payments (in } \\
\text { millions) })^{1,2}\end{array}$ & $\begin{array}{c}\text { Total } \\
\text { payments as } \\
\text { percentage of } \\
\text { health care } \\
\text { expenditures }\end{array}$ & $\begin{array}{c}\text { Payment } \\
\text { per } \\
\text { practicing } \\
\text { TX } \\
\text { physician }^{1,2}\end{array}$ & $\begin{array}{c}\text { Mean (in } \\
\text { thousands) }\end{array}$ & $\begin{array}{l}\text { Median (in } \\
\text { thousands) }{ }^{1,2}\end{array}$ & $\begin{array}{c}\text { Standard } \\
\text { deviation (in } \\
\text { thousands) }\end{array}$ & $\begin{array}{c}\text { Mean (in } \\
\text { thousands) }\end{array}$ & $\begin{array}{l}\text { Median (in } \\
\text { thousands) }^{1,2}\end{array}$ \\
\hline 1990 & 22,711 & 68,778 & 613 & 2.70 & 199 & $0.29 \%$ & 8,780 & 325 & 141 & 509 & 1,321 & 1,056 \\
\hline 1991 & 23,119 & 70,913 & 555 & 2.40 & 159 & $0.22 \%$ & 6,894 & 287 & 135 & 389 & 1,064 & 676 \\
\hline 1992 & 23,609 & 73,165 & 751 & 3.18 & 220 & $0.30 \%$ & 9,320 & 293 & 145 & 344 & 949 & 658 \\
\hline 1993 & 23,666 & 73,945 & 656 & 2.77 & 174 & $0.24 \%$ & 7,367 & 266 & 159 & 351 & 790 & 633 \\
\hline 1994 & 24,993 & 74,016 & 629 & 2.52 & 183 & $0.25 \%$ & 7,310 & 290 & 167 & 343 & 777 & 617 \\
\hline 1995 & 25,683 & 76,142 & 712 & 2.77 & 176 & $0.23 \%$ & 6,854 & 247 & 151 & 305 & 792 & 602 \\
\hline 1996 & 25,963 & 78,656 & 649 & 2.50 & 179 & $0.23 \%$ & 6,906 & 276 & 160 & 374 & 843 & 588 \\
\hline 1997 & 28,007 & 81,367 & 723 & 2.58 & 181 & $0.22 \%$ & 6,453 & 250 & 158 & 330 & 768 & 575 \\
\hline 1998 & 28,778 & 83,921 & 623 & 2.16 & 155 & $0.18 \%$ & 5,398 & 249 & 162 & 290 & 761 & 562 \\
\hline 1999 & 30,348 & 85,686 & 713 & 2.35 & 196 & $0.23 \%$ & 6,460 & 275 & 166 & 488 & 833 & 549 \\
\hline 2000 & 31,769 & 89,313 & 722 & 2.27 & 169 & $0.19 \%$ & 5,306 & 233 & 160 & 257 & 797 & 532 \\
\hline 2001 & 32,281 & 93,765 & 719 & 2.23 & 192 & $0.20 \%$ & 5,963 & 268 & 182 & 363 & 759 & 521 \\
\hline 2002 & 33,094 & 98,978 & 660 & 1.99 & 177 & $0.18 \%$ & 5,358 & 269 & 184 & 355 & 762 & 561 \\
\hline 2003 & 34,432 & 103,457 & 800 & 2.32 & 207 & $0.20 \%$ & 6,002 & 258 & 195 & 295 & 688 & 500 \\
\hline
\end{tabular}

1 after adjusting for bracket creep (see note 12 and accompanying text)

${ }^{2}$ including duplicates (see note 14 and accompanying text).

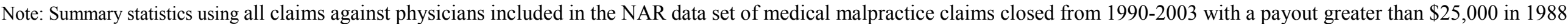

dollars. See Appendix for data sources 


\subsection{Data Limitations}

TDI's manner of collecting information on policy characteristics and claims creates particular data limitations for our study.

Policy Characteristics. Our dataset has several significant limitations. First, although the vast majority of Texas physicians are thought to carry liability insurance, ${ }^{17}$ the TCCD is not a representative sample of the insured physician population. It overrepresents doctors who experienced claims and under-represents doctors who did not. For this reason, the average policy limit reported in the TCCD might be higher or lower than the average limit for all insured Texas physicians. Physicians represented in the dataset also might disproportionately come from different specialties than physicians who are not represented. $^{18}$

Second, the TCCD is not a representative sample of Texas' physician population (insured and uninsured). Consequently, one cannot reliably generalize from our findings to all physicians practicing in Texas. Nor can one extrapolate easily to physicians practicing elsewhere in the United States. Financial responsibility requirements, damages caps, patient compensation funds, lawsuit screening panels, and other variations in tort regimes might affect liability insurance purchasing patterns. Despite this limitation, TCCD does capture the complete universe (ignoring data errors and the University of

\footnotetext{
${ }^{17}$ Comprehensive data on the fraction of physicians who carry insurance are unavailable. A 2003 report by the Texas Department of Insurance indicates that approximately 29,000 physicians obtained coverage through commercial insurers in 2001 (Texas Department of Insurance (2003). This number represents approximately $90 \%$ of all physicians practicing in the state that year.

${ }^{18}$ We attempted to evaluate the representativeness of the TCCD by requesting data on policy limit size from Physicians Insurance Association of America, an association of malpractice insurers, and the American Physicians Insurance Exchange, a liability carrier that sells malpractice coverage in Texas. The data were unavailable.
} 
Texas system ${ }^{19}$ ) of insured medical malpractice claims in Texas during our period of study. It therefore enables us to study compensation, deterrence, and personal exposure in cases where insurers fund payments in malpractice cases,

Third, we lack data on physician specialty, so we can say little about how limits vary by specialty. Fourth, we cannot determine whether nominal policy limits were eroded by payments on prior claims under the same policy. We therefore cannot identify cases where the payment was below the reported per occurrence limit but at or close to the remaining aggregate limit. Fifth, multiple policies might sometimes cover a single claim, such as when a doctor treats a patient over several years and acts performed in different years trigger different policies. We cannot measure the frequency of multiple coverage or its effects.

Claim Information. A prior study sets out the claim-related limitations of the TCCD (see Black et al. (2005, pp. 218-22)). We therefore highlight only certain limitations here. First, the TCCD contains information about injury type but not injury severity. Therefore, except when the injury is death, we cannot directly assess the degree of harm patients sustained. Second, as mentioned, the dataset contains no information about physician specialty. We do attempt to isolate perinatal cases, however, by separately analyzing claims with patients aged $0-1$ month at time of injury.

Evidence suggests that litigants sometimes engage in strategic behavior when settling malpractice lawsuits so physicians can avoid filing reports with the National

\footnotetext{
${ }^{19}$ For information on claims insured by the University of Texas system, see Medical Liability Benefit Plan 2005 Annual Report at http://www.utsystem.edu/ogc/MLAnnRep/mlannualrpt2005.pdf.
} 
Practitioner Data Bank (General Accounting Office, 1992). ${ }^{20}$ We cannot determine how often these strategies were employed or how they may have affected the number of cases in our dataset or doctors' insurance purchases.

\subsection{Legal Environment}

In 1977, Texas enacted a cap on compensatory damages in medical malpractice cases. In 1988, the Texas Supreme Court struck down the cap as it applied to negligence actions generally. ${ }^{21}$ In 1990, the first year for which closed claims are included in this study, the Court upheld the cap as applied to wrongful death claims. ${ }^{22}$ The wrongful death cap is indexed for inflation but otherwise did not change during our sample period. It equaled about $\$ 1,500,000$ in $2003 .{ }^{23}$ In our dataset, 3,363 cases (35\%) involved wrongful death claims.

\footnotetext{
${ }^{20}$ Some informed us that hospitals have an incentive to make payments to claimants in return for a promise from the claimant to drop the physician off the claim (or settle with the physician for an amount below any reporting threshold), especially if the physician generates substantial revenue for the hospital.

TDI does not require self-insured hospitals to file reports of closed claims. These hospitals make up a large portion of total hospitals; therefore, our data do not allow us to investigate whether or how these sorts of strategies might explain trends over time in policy purchases, claim payments or physician out-of-pocket payments.

${ }^{21}$ Lucas v. U.S. 757 S.W.2d 687 (Tex., 1988).

${ }^{22}$ The damages cap on wrongful death applies to all medical malpractice cases in which the plaintiff died. Rose v. Doctors Hosp., 801 S.W.2d 841, Tex.,1990 ("Like all actions based upon theories of negligence, the Roses' cause of action was a common law claim. It would have died with Rex Rose had it not been preserved by the legislature in the wrongful death statute.")

${ }^{23}$ Tex. Rev. Civ. Stat. Ann. art. 4590i, §§ 11.02, 11.04 (West Supp. 1998).
} 
During the period we study, Texas also enacted other tort reforms, ${ }^{24}$ including a cap on punitive damages, which varied depending on whether a case was filed before or after September 1, 1995. For earlier cases, the punitive damages cap was the greater of four times compensatory damages or $\$ 200,000$ (nominal). For later cases, the punitive cap was the greater of (1) $\$ 200,000$ (nominal) or (2) two times economic damages plus the greater of non-economic damages or $\$ 750,000 .{ }^{25}$ In our dataset, $4.3 \%$ of malpractice cases with jury verdicts contained punitive awards. For settled claims, we cannot confidently estimate the component that reflects the expected risk of a punitive damages award. $^{26}$

Finally, Texas, unlike many other states, does not require doctors to carry minimum coverage levels or demonstrate financial ability to pay claims. ${ }^{27}$ This is another reason why our findings on policy size and payments may not generalize to other states.

\footnotetext{
${ }^{24}$ In the mid-1990s Texas enacted a handful of reforms, some of which possibly apply to medical malpractice cases including changes in the applicability of contributory negligence to punitive damages (TX CIV PRAC \& REM § 33.002), general contributory negligence reform (TX CIV PRAC \& REM § 33.001), penalties for frivolous lawsuits (TX CIV PRAC \& REM § 10.001- 10,006), protection for good Samaritans (V.T.C.A., Civil Practice \& Remedies Code $\S 84.004$, TX CIV PRAC \& REM § 84.003), joint and several liability reform (TX CIV PRAC \& REM § 33.013), reform to arbitration rules in medical malpractice cases (Vernon's Ann.Civ.St. art. 4590i, § 15.01 (before Sept 1 2003); V.T.C.A., Civil Practice \& Remedies Code $§ 74.451$ (after 2003); (1993 Tex. Sess. Law Serv. Ch. 625 (S.B. 1409) (VERNON'S)) (for original session law)), general medical liability reform related to pretrial procedures (V.T.C.A., Civil Practice \& Remedies Code $\S 74.351$; TX LEGIS 140 (1995)/ (TX CIV ST Art. 4590i) and expert witness testimony (TX CIV ST Art. 4590i , V.T.C.A., Civil Practice \& Remedies Code $§ 74.401$ (after 9/1/03)), prejudgment interest reform (TX LEGIS 140 (1995) / (TX CIV ST Art. 4590i); V.T.C.A., Civil Practice \& Remedies Code $\S 41.006, \S 41.007$ since Sept 1, 1995), changes to burden of proof rules regarding punitive damages (TX CIV PRAC \& REM § 41.003), statute of limitations for minors (Weiner v. Wasson, 900 S.W.2d 316 (Tex. 1995), and venue reform (TX LEGIS 138 (1995)/ TX CIV PRAC \& REM § 15.002, TX CIV PRAC \& REM § 15.003). See Ronen Avraham. Database of State Tort Law Reforms (May 16, 2006). Northwestern Law \& Econ Research Paper No. 902711. http://ssrn.com/abstract=902711.

${ }_{25}$ Tex. Civ. Prac. \& Rem. Code Ann. § 41.008 (West 1997) (post-September, 1995 cap). The preSeptember, 1995 was found in Tex. Civ. Prac. \& Rem. Code Ann. § 41.007 (West 1991) (repealed 1995). The cap does not apply in cases of certain felonies, including fraudulent destruction or concealment of written records. Tex. Civ. Prac. \& Rem. Code Ann. § 41.008 (West 1997).

${ }^{26}$ Although TDI asks insurers to estimate the amount of a settlement that reflects punitive damages, we have no reason to rely on the insurer's assessment given that it is unclear how insurers can sensibly provide this breakdown in settled case.

${ }^{27}$ AMA, Liability Insurance Requirements, http://www.ama-assn.org/ama/pub/category/4544.html.
} 
It is also possible that changes in the legal environment during our period of study may contribute to changes in insurance policy size and payments.

\section{RESULTS}

In this Section we report on the relationship between policy limits and recoveries and the prevalence of physician out-of-pocket payments. We find that policy limits seem to cap recoveries in many cases and that primary insurers pay the vast majority of dollars to claimants, including the majority of dollars paid above the primary limits. These findings suggest that the financial deterrent from malpractice liability falls almost exclusively on insurers and is transmitted to physicians, if at all, through insurers' underwriting, pricing, and monitoring practices.

\subsection{Policy Limits as De Facto Caps on Recoveries}

To determine the relationship between payment amounts and policy limits, we began by computing payment-to-limit (PTL) ratios for all closed claims with no payment by an excess carrier. A $\$ 500,000$ payment on a $\$ 1$ million policy produces a PTL ratio of 0.5. The ratio equals 1 when the payment equals the primary policy limit.

Figure 1 shows the distribution of PTL ratios for all claims against physicians and for claims in perinatal cases (i.e., patients aged 0-1 month at time of injury). The spikes at the policy limits are obvious and large. 15.6\% (31.9\%) of all claims (perinatal claims) have ratios between 0.95 and 1 (inclusive), ${ }^{28}$ most claims in the spike $(13.6 \%(29.0 \%))$

\footnotetext{
${ }^{28}$ The percentage of non-perinatal claims with ratios between 0.95 and 1 is $13.6 \%(n=1,134)$. This percentage is statistically significantly lower than the percentage of perinatal claims in this range $(z=7.7 ; p$ $=0.00)$.
} 
have ratios of exactly $1 .^{29}$ We obtain similar distributions using various subsets of the data (e.g., claims involving only single or only multiple physicians, claims involving brain damage or death).

\section{FIGURE 1: Distributions of Payment-to-Limit Ratios}
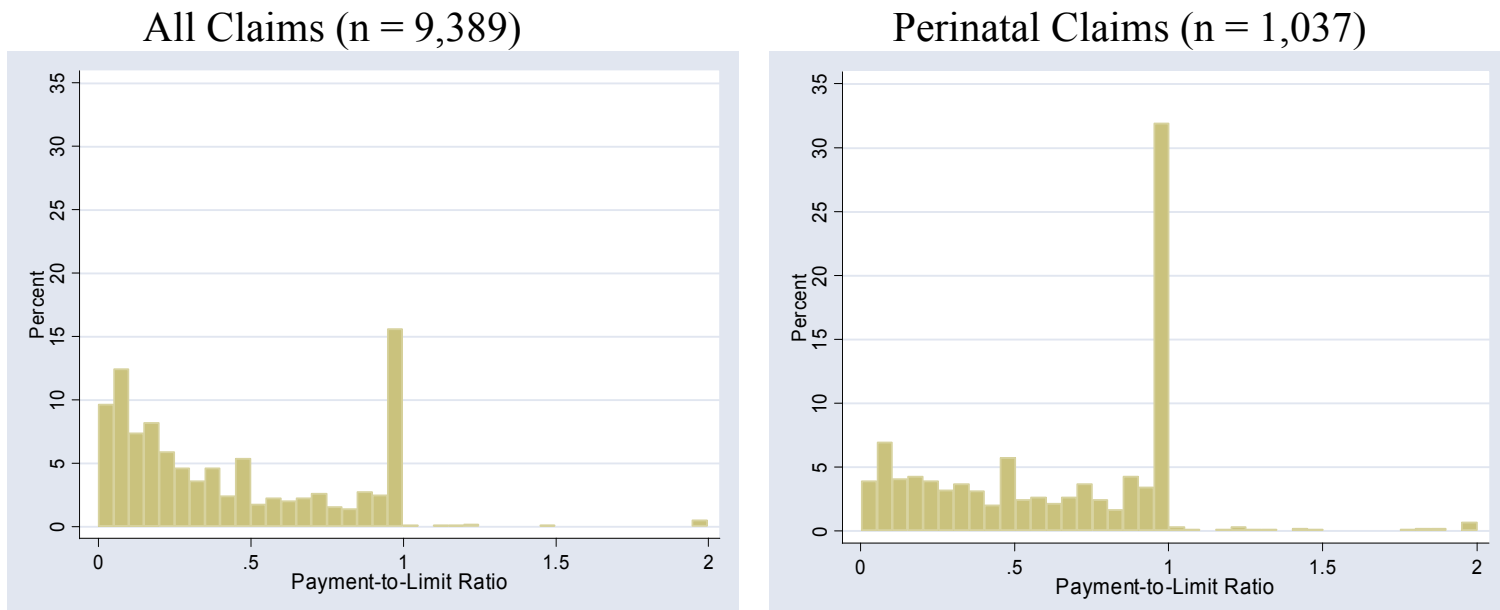

Note: Distributions of payment-to-limit ratios for all claims and for perinatal claims against physicians included in the NAR data set of medical malpractice claims closed from 1990-2003 with a payout greater than $\$ 25,000$ in 1988 dollars, including duplicates and excluding 260 claims with payments by excess carriers. Perinatal claims involved patients aged 0-1 month. Each bar represents a 0.05 increment. All claims with ratios greater than 2 were set equal to 2 .

Figure 2 displays trends in predicted probabilities of a claim payment made at the policy limit (PTL ratio equal to 1) across closing year. A logistic regression using all claims reveals no significant trend over time (odds ratio $=1.00 ; 95 \%$ confidence interval ("CI") $=[0.99,1.02])$. Using only perinatal claims, however, the same test reveals a statistically significant positive correlation between the likelihood of a claim payment made at the policy limit and closing year (odds ratio $=1.06 ; 95 \% \mathrm{CI}=[1.03,1.10]$ ). In

\footnotetext{
${ }^{29}$ Because we lack data on eroded limits, Figure 1 may understate the spike in payouts at available policy limits.
} 
other words, the probability of a claim closing at or just under the limits increased for perinatal claims but was constant for all claims.

\section{FIGURE 2: Predicted Probabilities of a Claim Payment at the Policy Limit by Year Claim Closed}

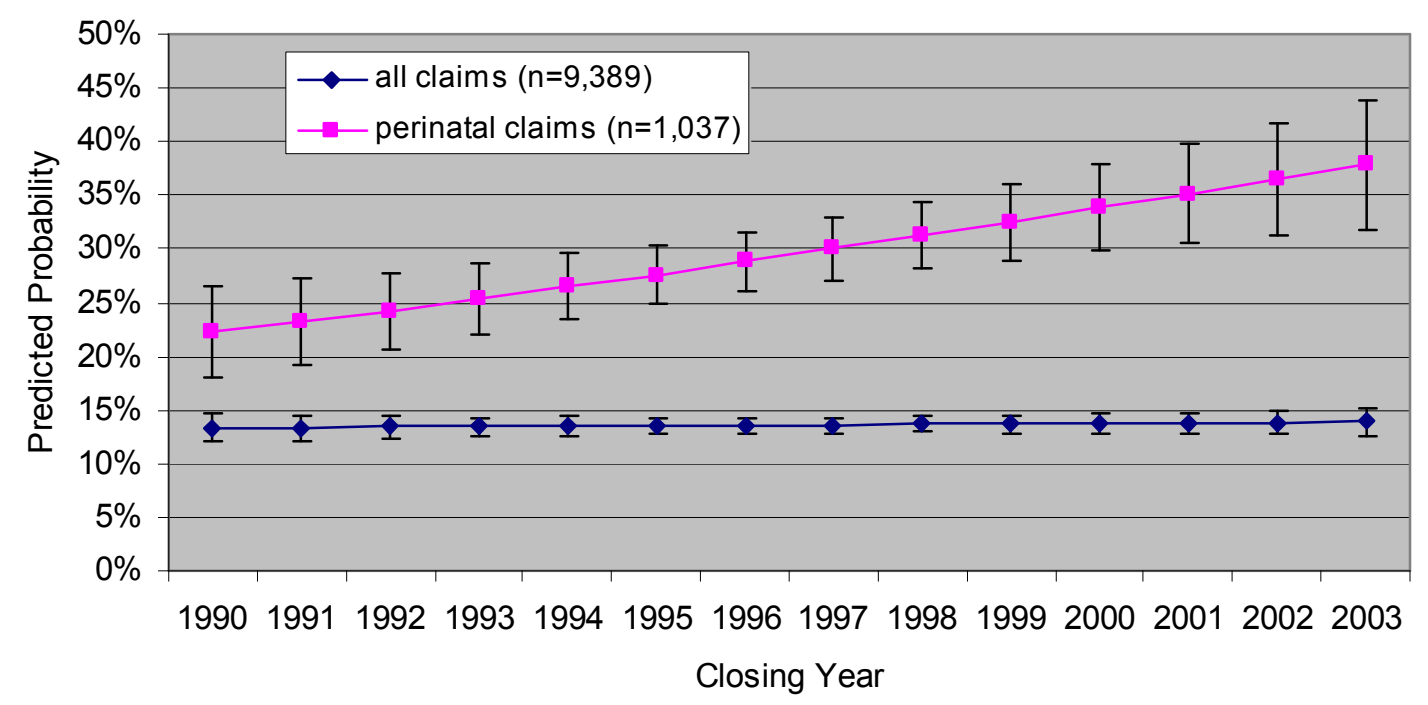

Trends in predicted probabilities of a claim payment at the policy limits by closing years 19902003 for all claims against physicians included in the NAR data set of medical malpractice claims closed from 1990-2003 with a payout greater than $\$ 25,000$ in 1988 dollars, including duplicates and excluding 260 claims with payments by excess carriers. Perinatal claims involved patients aged 0-1 month. Error bars represent $95 \%$ confidence intervals.

The magnitude of the at-limit spike in payments is sensitive to policy size. As

Figure 3 shows, it shrinks as policy size increases. For claims against physicians with real limits of greater than $\$ 1$ million, only 3.5\% closed with ratios between 0.95 and 1 (inclusive). By comparison, for policies between $\$ 500,001$ and $\$ 1$ million (real), $11 \%$ of payments fell into the spike; for policies between $\$ 250,001$ and $\$ 500,000$ (real), $25 \%$ fell into the spike; and for policies of $\$ 250,000$ (real) or less, $35 \%$ fell into the spike. Tests of equal proportions indicate that, with each step upward in policy size, the decrease in the percentage of claims with PTL ratios between 0.95 and 1 is statistically significant (i.e., 
$35.4 \%>25.3 \%(\mathrm{z}=5.5 ; \mathrm{p}=0.00) ; 25.3 \%>10.9 \%(\mathrm{z}=10.1 ; \mathrm{p}=0.00) ; 10.9 \%>3.5 \%(\mathrm{z}$

$=11.4 ; \mathrm{p}=0.00))$.

Figure 3: Distribution of Payment-to-Limit Ratios by Real Insurance Available in the Closing Year

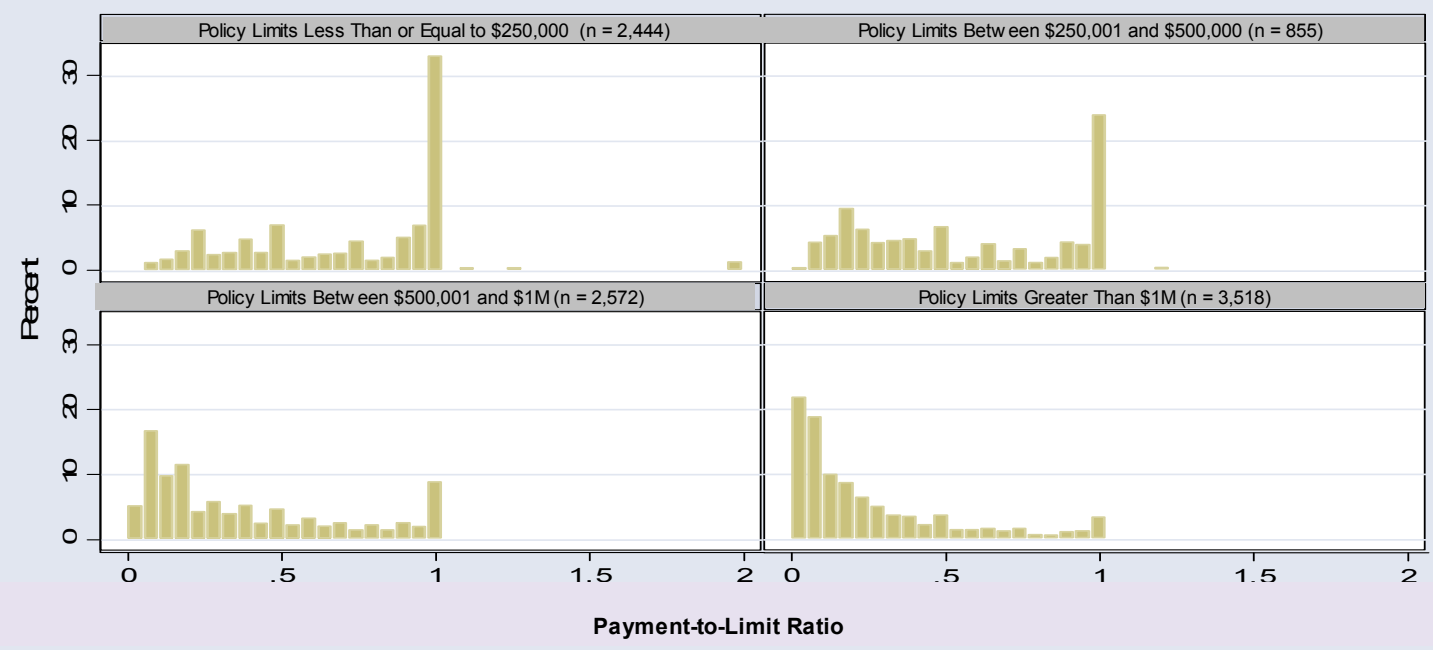

Note: Distributions of payment-to-limit ratios by real insurance available in the closing year for all claims against physicians included in the NAR data set of medical malpractice claims closed from 1990-2003 with a payout greater than $\$ 25,000$ in 1988 dollars, including duplicates and excluding 260 claims with payments by excess carriers. Each bar represents a 0.05 increment. All claims with ratios greater than 2 were set equal to 2 .

Only $1.5 \%$ of all claims $(2.4 \%$ of perinatal claims $)$ have PTL ratios $>1$. These payments are more frequent when policies are small, occurring in $3.7 \%$ of cases with real limits $\leq \$ 250,000$, but only $0.6 \%$ of cases with real limits of $\$ 1$ million or more (difference $=3.1 \%, 95 \% \mathrm{CI}=[2.3 \%, 3.8 \%]$ ). This result might reflect several factors: $(1)$ the underlying distribution of malpractice injuries, which includes many relatively minor injuries (Brennan et al. (1991); Studdert et al. (2000); Thomas et al. (2000); Thomas et al. (1999)); (2) the willingness of physicians to purchase smaller policies, which might be related to their personal exposure (though not in an obvious way, as our results for perinatal claims indicate); and (3) the willingness of plaintiffs (and their attorneys) to punish physicians who intentionally underinsure. 


\subsection{Who Pays?}

The low frequency of payments in excess of policy limits suggests that primary carriers bear most of the indemnity risk associated with paid malpractice claims. Table 3 provides a breakdown of the sources of payments on claims. ${ }^{30}$ Over $95 \%(9,059$ of 9,525$)$ of claims were resolved with primary carriers' money alone. This total includes 92 claims with PTL ratios $>1$, in which primary carriers paid more than the policy limits. Doctors contributed funds in excess of limits in $0.65 \%$ of the cases (an average of 4 such payments per year), with no apparent time trend in frequency. Measured in 2003 dollars, primary carriers paid $\$ 2.4$ billion at or below limits and $\$ 51$ million above limits; excess carriers paid $\$ 58.3$ million; and physicians paid $\$ 11.8$ million above the policy limits.

Payments by Primary Carriers. Primary carriers made payments in 9,512 of the 9,525 claims and contributed $96.8 \%$ of all dollars paid. Their payments varied considerably in size. Figure 4 shows the distribution of payments by primary carriers in real dollars. Primary carriers paid $\$ 500,000$ or less, measured in 2003 dollars, in $86.0 \%$ of the cases to which they contributed. The real mean (median) primary carrier payment was $\$ 261,000(\$ 161,000)$. A Cuzick (1985) nonparametric test for trend of real primary insurer payment size across ordered groups (i.e., year) found no significant time trend ( $\mathrm{z}$ $=-0.12, \mathrm{p}=0.90)$.

\footnotetext{
${ }^{30}$ The table does not include a breakdown of deductibles paid by physicians. Physicians paid a total of $\$ 11$ million (measured in 2003 dollars) in deductibles in 280 cases (263 in which primary carrier paid the balance and 17 cases in which others paid). The mean (median) real deductible was $\$ 39,000(\$ 25,000)$. Physicians paid deductibles of $\$ 100,000$ or more (real) in 20 cases, probably pursuant to self-insured retentions.
} 
Table 3: Sources of Funds Paid on Claims, 1990-2003

\begin{tabular}{|c|c|c|c|c|}
\hline $\begin{array}{c}\text { Payment by } \\
\text { Primary } \\
\text { Insurer? }\end{array}$ & $\begin{array}{c}\text { Payment by } \\
\text { Excess } \\
\text { Carrier? }\end{array}$ & $\begin{array}{l}\text { Out-of-pocket } \\
\text { Payment by }\end{array}$ & $\mathbf{N}$ & $\%$ \\
\hline $\mathrm{Y}$ & $\mathrm{N}$ & $\mathrm{N}$ & $9,322 *$ & $97.87 \%$ \\
\hline Y & Y & $\mathrm{N}$ & 128 & $1.34 \%$ \\
\hline Y & $\mathrm{N}$ & Y & 55 & $0.58 \%$ \\
\hline Y & Y & Y & 7 & $0.07 \%$ \\
\hline Other $^{\dagger}$ & & & 13 & $0.14 \%$ \\
\hline Total & & & 9,525 & $100.00 \%$ \\
\hline
\end{tabular}

Note: Sources of funds paid on claims against physicians included in the NAR data set of medical malpractice claims closed from 1990-2003 with a payout greater than \$25,000 in 1988 dollars (including duplicates).

* Deductibles were paid in 263 of these cases. The remaining 9,059 claims were resolved with primary carriers' money alone.

$\dagger$ Includes claims paid using only physician deductible $(\mathrm{n}=12)$ or only excess carrier funds and physician deductible $(n=1)$.

Primary carriers made payments in 1,051 perinatal cases $(11 \%$ of claims with primary carrier payments). The real mean (median) primary carrier payment for perinatal claims was $\$ 350,000(\$ 210,000)$, compared to a mean (median) payment of $\$ 250,000$ $(\$ 150,000)$ for non-perinatal claims. A Cuzick nonparametric test for trend of real primary insurer payment size across ordered groups (i.e., year) for perinatal claims produced a $\mathrm{z}$ of $-1.93(\mathrm{p}=0.05)$, suggesting that primary insurer payments in these cases decreased over this period.

Out-of-pocket Payments by Physicians. Physicians made out-of-pocket payments in 62 of the 9,525 cases $(0.65 \%)$. Physician out-of-pocket payments varied considerably in size: 38 were $\$ 100,000$ or less, 14 were $\$ 100,000-300,000,10$ were $\$ 300,000$ or more (all in 2003 dollars) (see Panel A of Figure 5). The real mean (median) was $\$ 190,000$ $(\$ 54,000)$. No significant time trend in real physician out-of-pocket payment size was 
detected (a Cuzick nonparametric test for trend across ordered groups produced a $\mathrm{z}$ of $0.51(\mathrm{p}=0.61))$

Figure 4: Distribution of Primary Carrier Payments

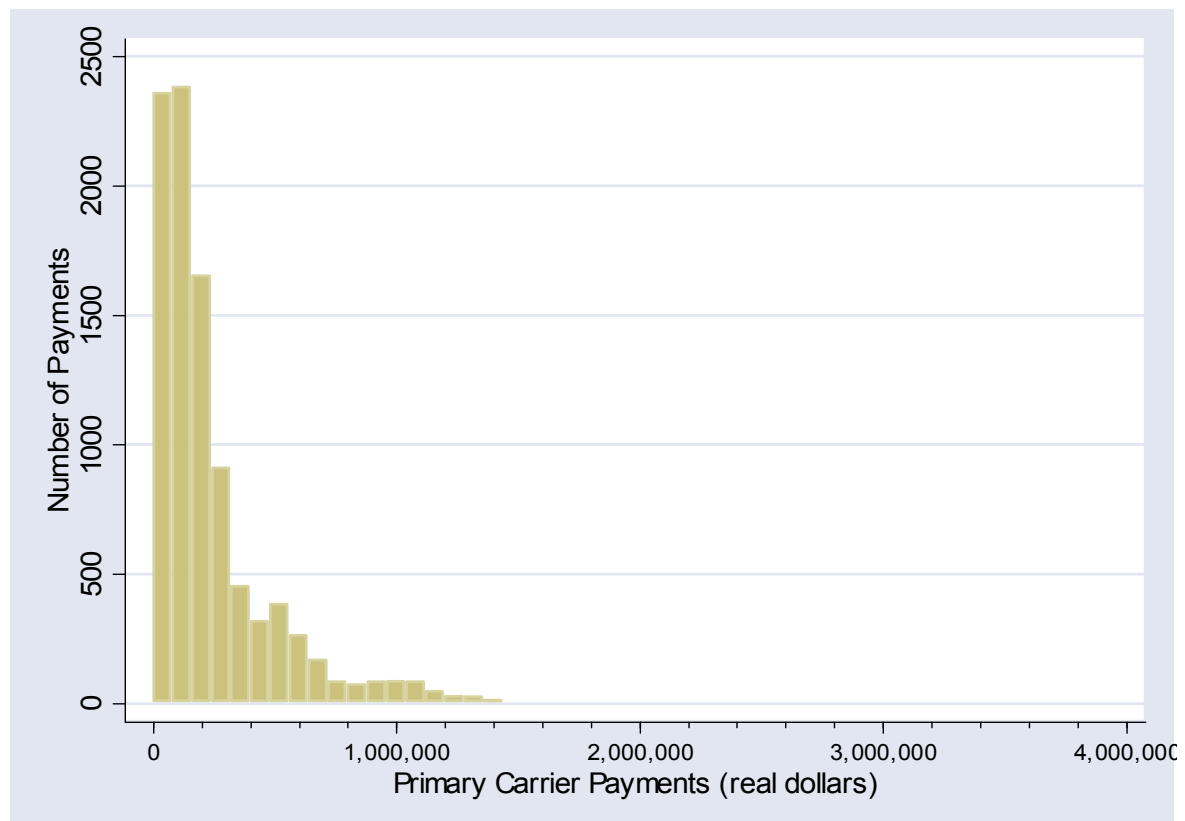

Note: Distribution of primary carrier payments related to all claims against physicians included in the NAR data set of medical malpractice claims closed from 1990-2003 with a payout greater than $\$ 25,000$ in 1988 dollars (including duplicates). Ten payments greater than $\$ 4 \mathrm{M}$ were set equal to $\$ 4 \mathrm{M}$. They range from $\$ 4 \mathrm{M}$ to \$10.2M.

The frequency of out-of-pocket payments varied by policy size, as shown in Figure 5, Panel B. These payments appeared most often when policy limits were $\$ 250,000$ or less, occurring in $1.3 \%$ of these cases $(32$ of 2,488$)$, compared to $0.4 \%$ of claims in cases with policies larger than $\$ 500,000(23$ of 6,160) (measured in 2003 dollars). A claims-level logistic regression finds that for each additional $\$ 100,000$ in real coverage (purchased by physicians who were sued and made total payments in excess of $\$ 25,000$ in 1988 dollars), the probability of an out-of-pocket payment fell by $0.05 \%$ ( $95 \%$ $\mathrm{CI}=[0.01 \%, 0.08 \%])$. When considering only claims with PTL ratios $>0.9(47$ of the 62 
out-of-pocket payments fall into this group), however, we find no statistically significant correlation between the likelihood of making an out-of-pocket payment and policy size $(\mathrm{OR}=1 ; 95 \% \mathrm{CI}=[0.9999998,1.0000001] ; \mathrm{n}=1,910)$, suggesting that the unconditional marginal difference is driven by the fact that actual damages are more likely to exceed policy limits when limits are low.

In 18 of the 62 cases in which physicians made out-of-pocket payments, primary insurers paid less than the reported policy limits. Possible explanations for this pattern include eroded primary limits, settlement dynamics between physicians and insurers and coverage disputes.

\section{Figure 5: Physician Out-of-Pocket Payments}

Panel A: Distribution $(\mathrm{n}=62)$

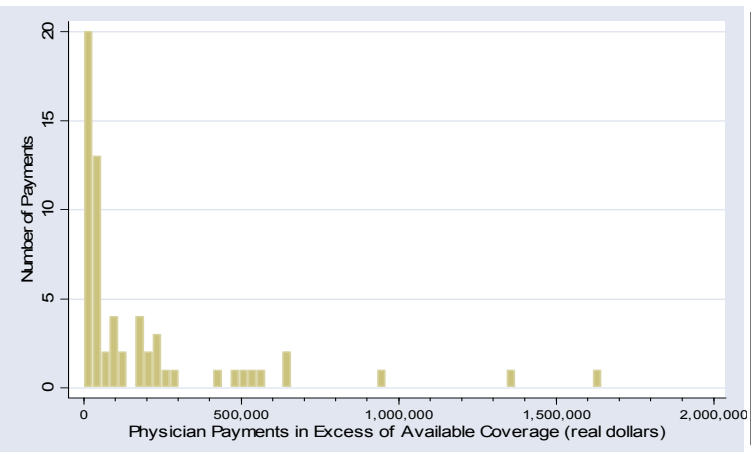

Panel B: Percent with Payments by Policy Limit Size

Panel A: Distribution of physician out-of-pocket payments in excess of available coverage related to all claims against physicians included in the NAR data set of medical malpractice claims closed from 19902003 with a payout greater than $\$ 25,000$ in 1988 dollars (including duplicates). Panel B: Percent of claims closed with physician out-of-pocket payments by policy limit size (in 2003 dollars) using same dataset.

Perinatal cases, which account for $11 \%$ of all paid claims, generated $26 \%$ of outof-pocket payments (16 of 62). The real mean (median) out-of-pocket payment for perinatal claims was $\$ 270,000(\$ 120,000)$, compared to $\$ 160,000(\$ 40,000)$ for nonperinatal claims. A logit regression controlling for real policy limit and real payment, however, finds no statistically significant correlation between the perinatal nature of a 
case and the likelihood of making an out-of-pocket payment $(\mathrm{OR}=0.84 ; 95 \%$ $\mathrm{CI}=[0.19,3.71])^{31}$

Although we do not attempt to explore the causes of out-of-pocket payments, claims with these payments have certain prominent features. They are much larger on average than claims in general: the mean total payment (2003\$) for claims with physician out-of-pocket payments is $\$ 640,000$ as compared to $\$ 270,000$ for all claims. As Table 4 shows they also are more likely than claims in general to involve brain damage and infants; and they are less likely than claims in general to be death cases (but only at the $10 \%$ level). These observations are not surprising. Larger claims are more likely to exceed policy limits, and brain damage and infant plaintiffs are known to correlate positively with payment size. By contrast, death is sometimes correlated with lower total payments relative to injuries requiring future medical care (see e.g., Studdert et al. (2004); but see Black et al. (2007)).

Claims resolved after plaintiff verdicts were also associated with more frequent above-limits payments. Table 5 reveals that doctors contributed to resolutions in $4.6 \%$ (9/196) of claims with pro-plaintiff verdicts, but the burden of above-limits verdicts still fell more heavily on primary insurers, which paid more than the limits $17.8 \%(35 / 196)$ of the time. At almost every verdict level, primary carriers were more likely to make abovelimit payments than physicians were to make out-of-pocket payments, and also paid

\footnotetext{
${ }^{31} \mathrm{We}$ constructed four categories of available coverage amounts $(\$ 0-\$ 250 \mathrm{~K}, \$ 250,001-\$ 500 \mathrm{~K}, \$ 500,001$ $\$ 1 \mathrm{M}$ and $>\$ 1 \mathrm{M}$ ) and four categories of total payment size (using the same categories). We then estimated a logistic regression using a binary variable to capture the effect of perinatal cases, the categorical variable for payment size, the categorical variable for policy limit and interactions between these three variables (to increase goodness of fit). Given the small number of perinatal claims with out-of-pocket payments by physicians, the power of the test might be too low to detect an effect given one exists.
} 


Table 4: The Influence of Various Claim Characteristics on the Likelihood of
Physician Out-of-Pocket Payments

* Similar results obtained using Cuzick's test for trend.

Note: Counts of all claims against physicians included in the NAR data set of medical malpractice claims closed from 1990-2003 with a payout greater than $\$ 25,000$ in 1988 dollars (including duplicates) with physician out-of-pocket payments. $35 \%$ of all claims involved death, $10 \%$ involved brain damage and $12 \%$ involved victims aged 1 year or less.

larger amounts. For example, in the 20 cases with the largest verdicts ( $>\$ 5$ million), doctors made one out-of-pocket payment, while primary carriers paid more than the limits eight times. Primary carriers may have several reasons for agreeing to pay above limits: (1) they might fear bad-faith-refusal-to-settle claims by insured physicians; ${ }^{32}$ (2) when the insurer wants to defend at trial, agreeing to protect the physician against out-ofpocket liability might help encourage the physician to go along; (3) when the physician wants to try the case, agreeing to pay above limits might encourage the physician to settle; and (4) when a plaintiff with a strong case demands more than the limits, waiving the limits might be a rational means of avoiding additional defense costs associated with trial, or protecting the physician against an out-of-pocket payment (providing this protection might have reputational value for the insurer).

\footnotetext{
${ }^{32}$ In Texas, a carrier that rejects an offer to settle at or within policy limits may have to pay more than the limits when a jury subsequently returns a verdict for the plaintiff in a larger amount. See G. A. Stowers Furniture Co. v. American Indemnity Co., 15 S.W.2d 544 (Tex. Comm. App. 1929, holding approved).
} 
Table 6 compares the verdict to the policy limit and examines physician payments in light of this relationship. In 91 cases with verdict-to-policy limit ratios $>1$, physicians made seven out-of-pocket payments (7.7\%), and each payment was $\$ 200,000$ or less. Although one might have suspected that the frequency of out-of-pocket payments would rise with the verdict-to-policy limit ratio (as a penalty imposed by the plaintiff for being grossly underinsured), this was not observed. In the 31 cases with the highest verdict-topolicy limit ratios $(>5)$, only one out-of-pocket physician payment appears. The principal consequence of limits that are less than the verdict appears to be lower recoveries for plaintiffs, who collect declining percentages of verdicts as the ratio of verdict to policy limits rises. ${ }^{33}$

\section{Table 5: Physician Out-of-Pocket Payments and Primary Insurer Above-Limit Payments in Claims Resolved After Plaintiff Jury Verdicts}

\begin{tabular}{ccccccccc}
\hline $\begin{array}{c}\text { Verdict } \\
\text { size } \\
(2003 \$)\end{array}$ & $\mathrm{N}$ & $\begin{array}{c}\text { Average } \\
\text { Total } \\
\text { Payment* }\end{array}$ & $\begin{array}{c}\text { Number } \\
\text { of out-of- } \\
\text { pocket } \\
\text { payments } \\
\text { by doc }\end{array}$ & $\begin{array}{c}\text { Mean } \\
\text { payment by } \\
\text { doc }\end{array}$ & $\begin{array}{c}\text { Maximum } \\
\text { payment by } \\
\text { doc }\end{array}$ & $\begin{array}{c}\text { Number } \\
\text { of above- } \\
\text { limit } \\
\text { payments } \\
\text { by } \\
\text { primary } \\
\text { insurer }\end{array}$ & $\begin{array}{c}\text { Mean } \\
\text { above-limit } \\
\text { payment by } \\
\text { primary } \\
\text { insurer }\end{array}$ & $\begin{array}{c}\text { Max above- } \\
\text { limit } \\
\text { payment by } \\
\text { primary } \\
\text { insurer }\end{array}$ \\
$0-1 \mathrm{M}$ & 116 & $\$ 275$ & 4 & $\$ 87$ & $\$ 211$ & 12 & $\$ 66$ & $\$ 169$ \\
$1 \mathrm{M}-2 \mathrm{M}$ & 29 & $\$ 885$ & 2 & $\$ 102$ & $\$ 176$ & 7 & $\$ 374$ & $\$ 988$ \\
$2 \mathrm{M}-3 \mathrm{M}$ & 13 & $\$ 1,378$ & 1 & $\$ 172$ & $\$ 172$ & 6 & $\$ 647$ & $\$ 1,757$ \\
$3 \mathrm{M}-4 \mathrm{M}$ & 10 & $\$ 1,118$ & 1 & $\$ 213$ & $\$ 213$ & 2 & $\$ 232$ & $\$ 270$ \\
$4 \mathrm{M}-5 \mathrm{M}$ & 8 & $\$ 1,718$ & 0 & $\mathrm{~N} / \mathrm{A}$ & $\mathrm{N} / \mathrm{A}$ & 0 & $\mathrm{~N} / \mathrm{A}$ & $\mathrm{N} / \mathrm{A}$ \\
$5 \mathrm{M}+$ & 20 & $\$ 2,507$ & 1 & $\$ 87$ & $\$ 87$ & 8 & $\$ 2,036$ & $\$ 6,338$ \\
Total & 196 & & 9 & & & 35 & & \\
\hline
\end{tabular}

Note: Physician out-of-pocket payments and primary insurer above-limit payments in claims resolved after plaintiff jury verdicts related to all claims against physicians included in the NAR data set of medical malpractice claims closed from 1990-2003 with a payout greater than $\$ 25,000$ in 1988 dollars (excluding duplicates) that were closed after a plaintiff jury verdict. Amounts in thousands of 2003 dollars.

* "Total payment" includes payments by physician, primary insurer and excess carrier. Note that average total payments fall below lower bound of verdict ranges in all but one case. See Hyman, et al. (2007) for complete analysis of the differences between jury awards and amounts plaintiffs receive.

\footnotetext{
${ }^{33}$ For additional analysis of payments after verdicts, see Hyman et al. (2007).
} 
Table 6: Physician Out-of-Pocket Payments by Ratio of Plaintiff Jury Verdict-to-Policy Limit

\begin{tabular}{cccccc}
\hline $\begin{array}{c}\text { Ratio: } \\
\text { jury } \\
\text { verdict/ } \\
\text { policy } \\
\text { limit }\end{array}$ & $\begin{array}{c}\text { Number } \\
\text { of cases }\end{array}$ & $\begin{array}{c}\text { Mean } \\
\text { (median) } \\
\% \text { of } \\
\text { verdict } \\
\text { paid }\end{array}$ & $\begin{array}{c}\text { Mean out-of- } \\
\text { pocket } \\
\text { payment by } \\
\text { doc in all pro- } \\
\text { plaintiff } \\
\text { verdict cases }\end{array}$ & $\begin{array}{c}\text { Mean out-of- } \\
\text { pocket payment } \\
\text { by doc in cases } \\
\text { with doc out-of- } \\
\text { pocket payments } \\
\text { only }\end{array}$ & $\begin{array}{c}\text { Number } \\
\text { of cases } \\
\text { with out- } \\
\text { of-pocket } \\
\text { payments } \\
\text { by doc }\end{array}$ \\
$0-1$ & 105 & $84.8 \%$ & $\$ 2.1$ & $\$ 113$ & 2 \\
$1-2$ & 36 & $72.2 \%$ & $\$ 3.4$ & $\$ 62$ & 2 \\
$2-3$ & 13 & $51.8 \%$ & $\$ 13.3$ & $\$ 172$ & 1 \\
$3-4$ & 5 & $29.7 \%$ & $\$ 35.2$ & $\$ 176$ & 1 \\
$4-5$ & 6 & $34.4 \%$ & $\$ 19.2$ & $\$ 58$ & 2 \\
$>5$ & 31 & $24.3 \%$ & $\$ 6.9$ & $\$ 213$ & 1 \\
Total & 196 & & & & 9 \\
\hline
\end{tabular}

Note: Physician out-of-pocket payments by ratio of plaintiff jury verdict-to-policy limit related to all claims against physicians included in the NAR data set of medical malpractice claims closed from 1990-2003 with a payout greater than $\$ 25,000$ in 1988 dollars (excluding duplicates) that were closed after a plaintiff jury verdict. Amounts in thousands of 2003 dollars.

The statistics on out-of-pocket payments discussed in this section reflect cases with pro-plaintiff verdicts that ended with payments to claimants. Studies typically find that defendants win $70-80 \%$ of medical malpractice trials (Cohen (2004)). Taking these defense verdicts into account, the estimated likelihood of a physician out-of-pocket payment in a tried case (as opposed to a tried case that yielded a plaintiff verdict) was about $1 \% .^{34}$

\subsection{Primary Policy Size}

The conventional wisdom is that most doctors buy medical malpractice policies with $\$ 1$ million per occurrence limits (Cheney (1999), Quinn (1998), American College of Emergency Physicians (2004)). For Texas physicians with paid claims, the data do not support this belief. The median policy limit was $\$ 500,000$ (nominal) and was constant

\footnotetext{
${ }^{34}$ If we assume that $75 \%$ of trials produced defense verdicts, the fraction of total trials that resulted in outof-pocket payments is estimated to be $1 / 4$ of the $4.6 \%$ reported in text, or $1.2 \%$.
} 
during our sample period. Only $31 \%$ of the policies in our sample had limits of $\$ 1$ million and $6 \%$ had limits of more than $\$ 1$ million, while 32\% had nominal limits of $\$ 200,000$ or less.

Figure 6 shows the percentage of all paid claims covered by policies purchased 1988 -1999 with the most common nominal limits- $\$ 100,000, \$ 200,000, \$ 500,000, \$ 1$ million, and \$2 million. Ninety-two percent of primary policies purchased in these years fell into one of these five categories. Although policies with $\$ 1$ million nominal limits were the most common type, only about one-third of the policies reported were of this size, and few (6.1\%) were larger. Policies with limits of $\$ 100,000, \$ 200,000$, and $\$ 500,000$ collectively appear in more than half the paid claim reports.

Figure 6: Percentage of Policies Purchased by Per Occurrence Limit (in nominal dollars) and Purchase Year

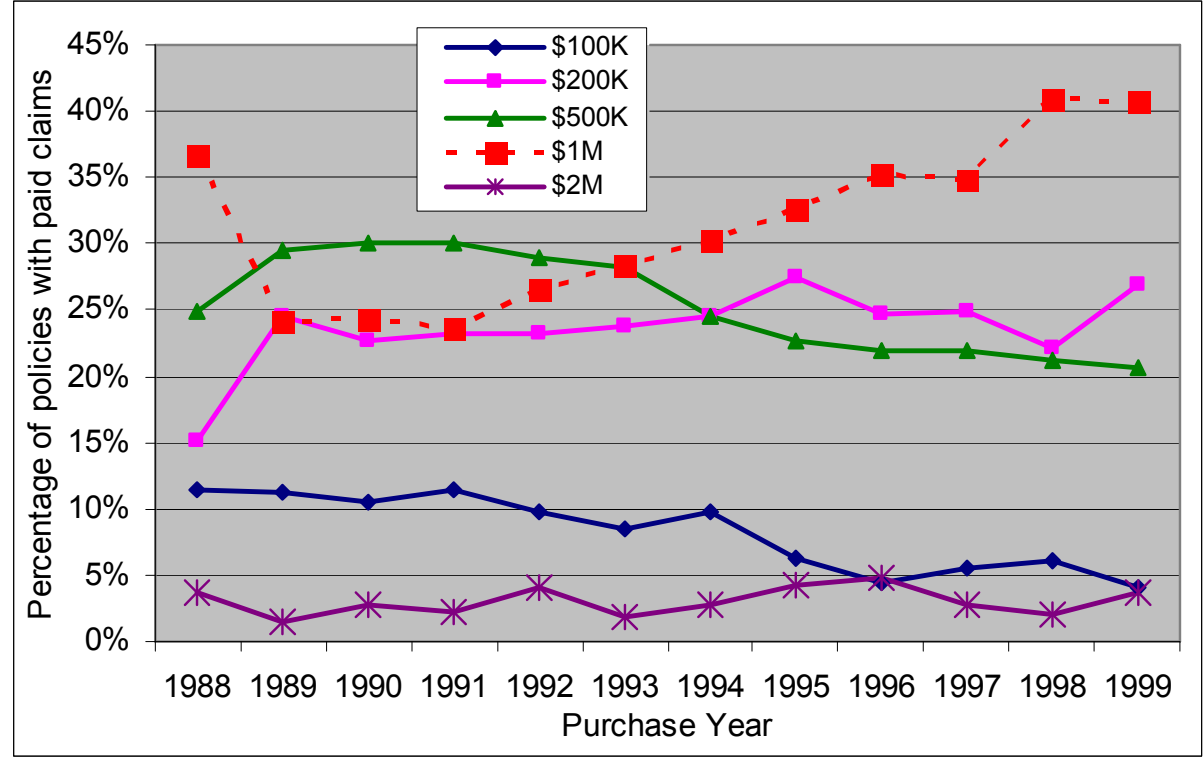

Note: Percentage of policies purchased by per occurrence limit (in nominal dollars) and purchase year calculated using all claims against physicians included in the NAR data set of medical malpractice claims closed from 1990-2003 with a payout greater than \$25,000 in 1988 dollars (including duplicates) that were made against policies purchased 1988-1999. The sum of percentages for each purchase year do not equal $100 \%$ as physicians purchased small numbers of policies of sizes other than those included here. On average across purchase years, $0.1 \%$ of policies purchased had limits of less than $\$ 100 \mathrm{~K}, 0 \%$ between $\$ 100 \mathrm{~K}$ and $\$ 200 \mathrm{~K}, 2 \%$ between $\$ 200 \mathrm{~K}$ and $\$ 500 \mathrm{~K}, 3 \%$ between $\$ 500 \mathrm{~K}$ and $\$ 1 \mathrm{M}, 1 \%$ between $\$ 1 \mathrm{M}$ and $\$ 2 \mathrm{M}$, and $2 \%$ above $\$ 2 \mathrm{M}$. 
Policies with $\$ 100,000$ nominal limits made up a declining percentage of total policies over this period, ${ }^{35}$ but the combined percentage of $\$ 100,000$ and $\$ 200,000$ policies showed no significant time trend. ${ }^{36}$ This may suggest that physicians switched from $\$ 100,000$ policies to $\$ 200,000$ policies over time. Alternatively, plaintiffs may have sued doctors with $\$ 100,000$ policies less often. The data do not allow us to determine which phenomenon, if either, explains the observed pattern.

Figure 7 provides summary statistics on real coverage amounts purchased by year, separately for physicians involved in perinatal and non-perinatal cases. From 1988 to 1999 mean and median nominal policy limits purchased were stable (the median policy size in each year was $\$ 500,000$ ) but real mean and median limits for physicians involved in both perinatal claims and non-perinatal claims each fell by roughly $30 \%$ from 1988 to 1999. The decline was significant (a Cuzick nonparametric test for trend across ordered groups produced a $\mathrm{z}$ of $-7.09(\mathrm{p}=0.00)$ for perinatal claims and $-12.70(\mathrm{p}=0.00)$ for non-perinatal claims).

Perinatal physicians carried less insurance than other physicians. In 1988, perinatal physicians purchased mean coverage of $\$ 931,000$ (measured in 2003 dollars), versus $\$ 1,138,000$ for other physicians $(\operatorname{diff}=\$ 207,000$; one-tailed $t$-test produced $t=$ $1.8, \mathrm{p}=0.036)$ ). In 1999 , perinatal physicians purchased $\$ 636,000$ of real coverage on average versus $\$ 777,000$ for other physicians (diff $=\$ 141,000$; one-tailed t-test produced $\mathrm{t}=1.3 ; \mathrm{p}=0.0997)$.

\footnotetext{
${ }^{35}$ The estimated marginal effect of each year on percentage of total policies equal to $\$ 100 \mathrm{~K}$ nominal is $0.7 \%(95 \% \mathrm{CI}=[-0.9 \%,-.0 .5 \%])$.

${ }^{36}$ The estimated marginal effect of each year on percentage of total policies equal to $\$ 100 \mathrm{~K}$ or $\$ 200 \mathrm{~K}$ nominal is $-0.2 \%(95 \% \mathrm{CI}=[-0.7 \%, 0.3 \%])$.
} 
Figure 7: Physician Policy Size by Purchase Year

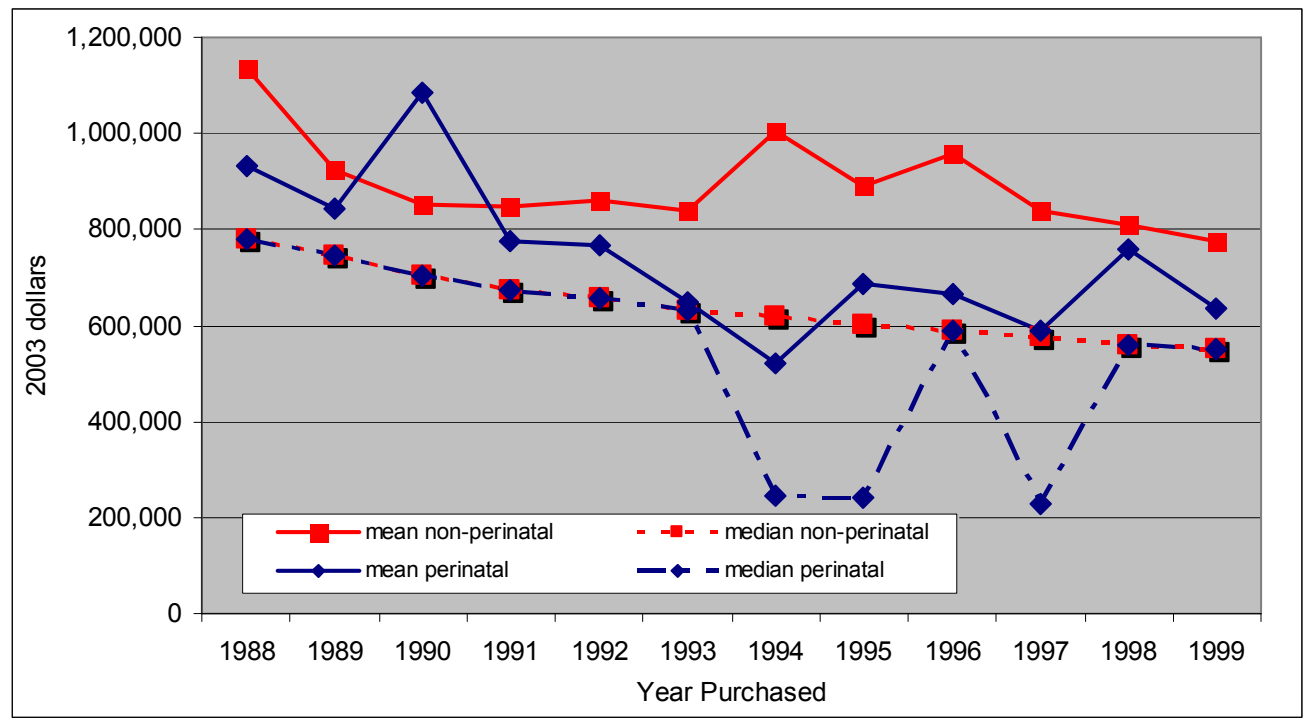

Note: Mean and median policies purchased by purchase year for related to closed claims against policies purchased 1988-1999 by perinatal and non-perinatal physicians included in the NAR data set of medical malpractice claims closed from 1990-2003 with a payout greater than $\$ 25,000$ in 1988 dollars (including duplicates).

Because median real policy size for perinatal physicians and other doctors is similar, the lower mean for perinatal physicians must reflect a relative dearth of policies with high limits: $30.5 \%$ of perinatal claims involved policies with nominal limits $\geq \$ 1$ million versus $43.2 \%$ of claims involving other physicians (diff=12.7\%; 95\% $\mathrm{CI}=[9.7 \%, 15.7 \%])$. Although perinatal physicians tend to face larger claims, they are less likely than other doctors to carry relatively large insurance policies.

\subsection{Claim Frequencies and Total Payments}

Given that policy size declined and that policy limits often cap recoveries, one might expect that, all else equal, payment per claim might also decline. If policies decline substantially, this might impact claim frequencies as well. We found that claim rates remained steady or declined over the period, while payment amounts remained stable. 
This could reflect two offsetting trends - underlying real potential damages might have increased (due to medical costs rising faster than prices in general) at the same time that real policy limits declined.

Figure 8 provides trends in the number of large paid claims per closing year adjusted for overall population growth, growth in the number of practicing physicians and medical expenditures (2003\$). The number of claims per 1 million Texas residents was stable across time $;{ }^{37}$ the number per 1,000 Texas physicians declined somewhat; ${ }^{38}$ and the number per $\$ 1$ billion in medical expenditures by Texas residents also dropped. ${ }^{39}$

Figure 9 provides trends for average total payment per claim by closing year. At the claim level, we found no significant trend in payment size (a Cuzick nonparametric test for trend produced a $\mathrm{z}$ of $-0.45(\mathrm{p}=0.65)$; OLS estimate is consistent with nonparametric test). ${ }^{40}$ At an annual aggregate level, however, the mean decreased over time while the median increased. ${ }^{41}$ This suggests changes in the distribution of payment size over time. In fact, payments exceeding $\$ 1 \mathrm{M}(2003 \$)$ comprised $6.5 \%$ of the claims in 1990 compared with $2.5 \%$ in 2003 . At the low end, cases with payments of less than $\$ 100,000$ (2003\$) comprised 35\% of the claims in 1990 compared with 31\% in 2003 .

\footnotetext{
37 An OLS regression of number of claims per 1 million Texas residents against year estimates a statistically insignificant average annual decrease of 0.25 claims per year $(95 \% \mathrm{CI}=[-0.68,0.18])$.

${ }^{38}$ An OLS regression of number of claims per 1,000 non-federal physicians in active practice in Texas against year estimates an annual decrease of 0.53 claims per year $(95 \% \mathrm{CI}=[-0.85,-0.21])$.

${ }^{39}$ An OLS regression of number of claims per $\$ 1$ billion in medical expenditures by Texas residents against year estimates an annual decrease of 0.31 claims per year $(95 \% \mathrm{CI}=[-0.42,-0.19])$.

The trends reported here for number of large paid claims against physicians, adjusted for overall population and number of physicians are similar to those reported for large paid claims against all health care providers in Black et al. (2005). This article did not study the number of large paid claims relative to overall medical expenditures.

${ }^{40}$ The lack of trend for payout per large paid claim against physicians is similar to that reported for large paid claims against all health care providers in Black et al. (2005), for 1988-2002 (extended to 2004 in unreported work).

${ }^{41}$ Using all claims, an OLS regression of annual mean payment against year estimates an average annual decrease of $\$ 4,000$ per year $(95 \% \mathrm{CI}=[-6,300,-800])$. An OLS regression of annual median payment against year estimates a average annual increase of $\$ 3,500$ per year $(95 \% \mathrm{CI}=[2,400,4,700])$.
} 
FIGURE 8: Trends in Number of Claims Adjusted for Population, Physician Population and Medical Expenditures

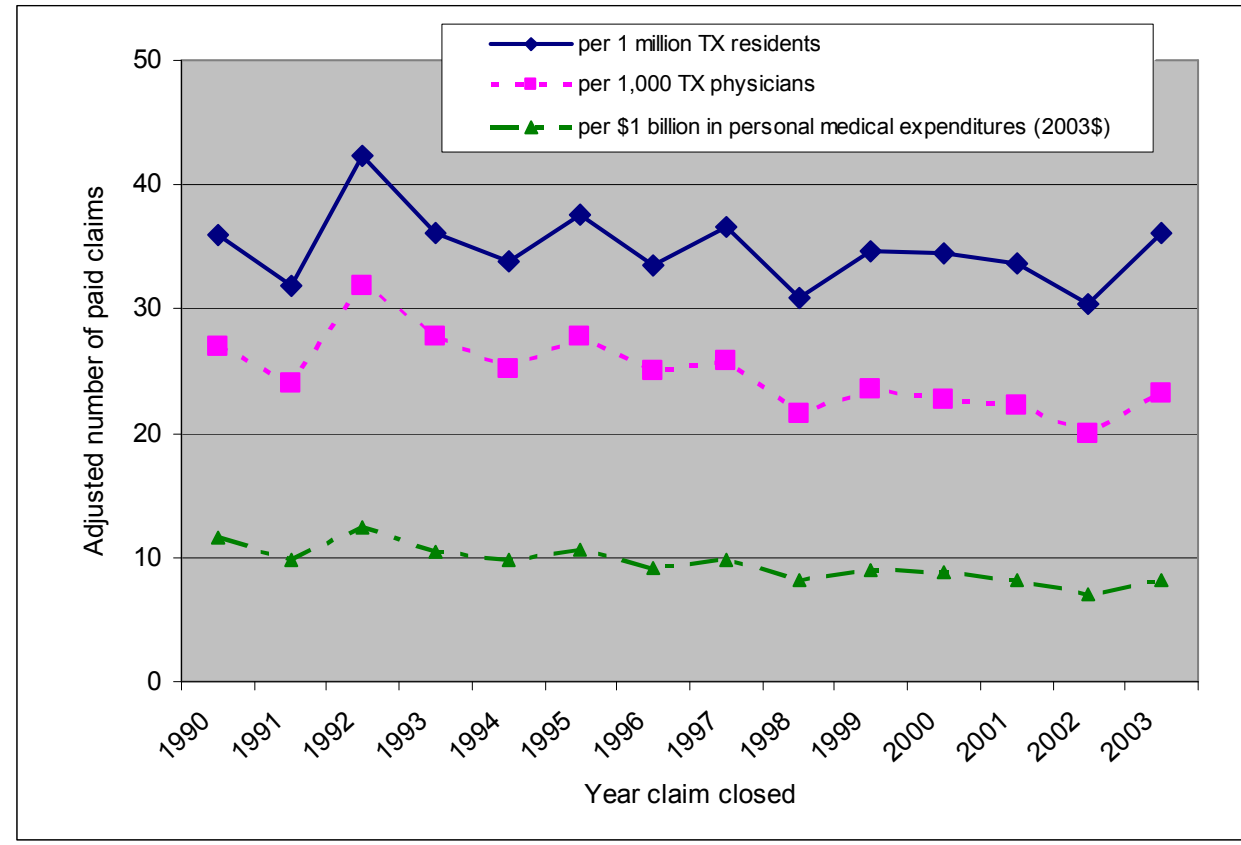

Note: Trends in number of claims adjusted for population, physician population and medical expenditures for all claims against physicians included in the NAR data set of medical malpractice claims closed from 1990-2003 with a payout greater than $\$ 25,000$ in 1988 dollars (including duplicates).

FIGURE 9: Trends in Total Payment per Claim (thousands of 2003\$)

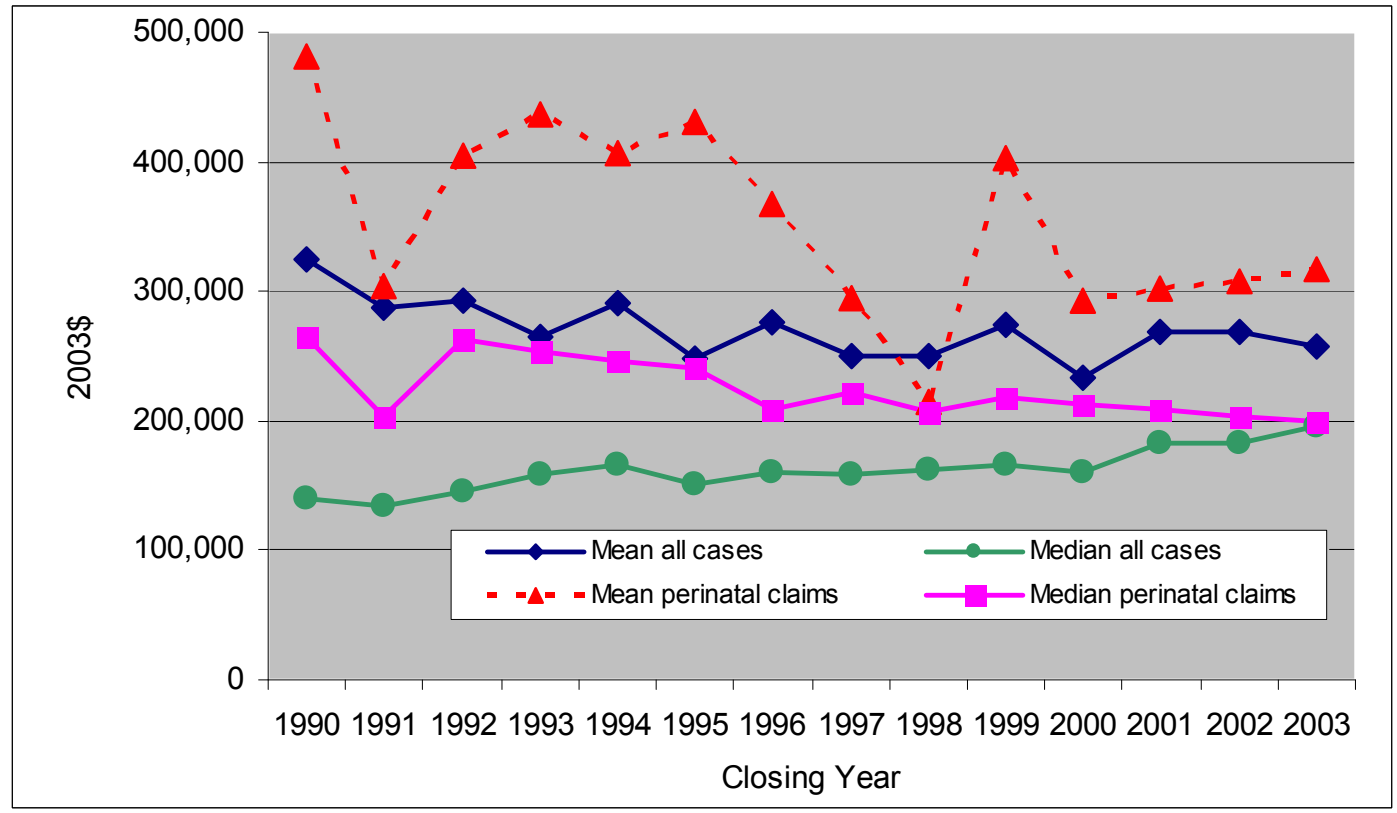

Note: Trends in total payment per claim (measured in thousands of 2003 dollars) for all claims against physicians included in the NAR data set of medical malpractice claims closed from 19902003 with a payout greater than $\$ 25,000$ in 1988 dollars (including duplicates). 
Perinatal claims saw decreases in the annual mean and median real payment. ${ }^{42}$ At the claim level, we detected a weakly significant downward trend in real total payment size (a Cuzick nonparametric test for trend produced a $\mathrm{z}$ of $-1.91(\mathrm{p}=0.06)$; OLS estimate is consistent with the nonparametric test but not statistically significant at the $10 \%$ level).

Finally, we observed a decline in average total payment per non-federal physician in active practice in Texas (see Figure 10). ${ }^{43}$ An OLS regression of average total payment against year estimates an average annual decrease of $\$ 152$ per year $(95 \% \mathrm{CI}=[-217,-87])$.

Figure 10: Average Total Payment per Non-Federal Physician in Active Practice in Texas (2003\$)

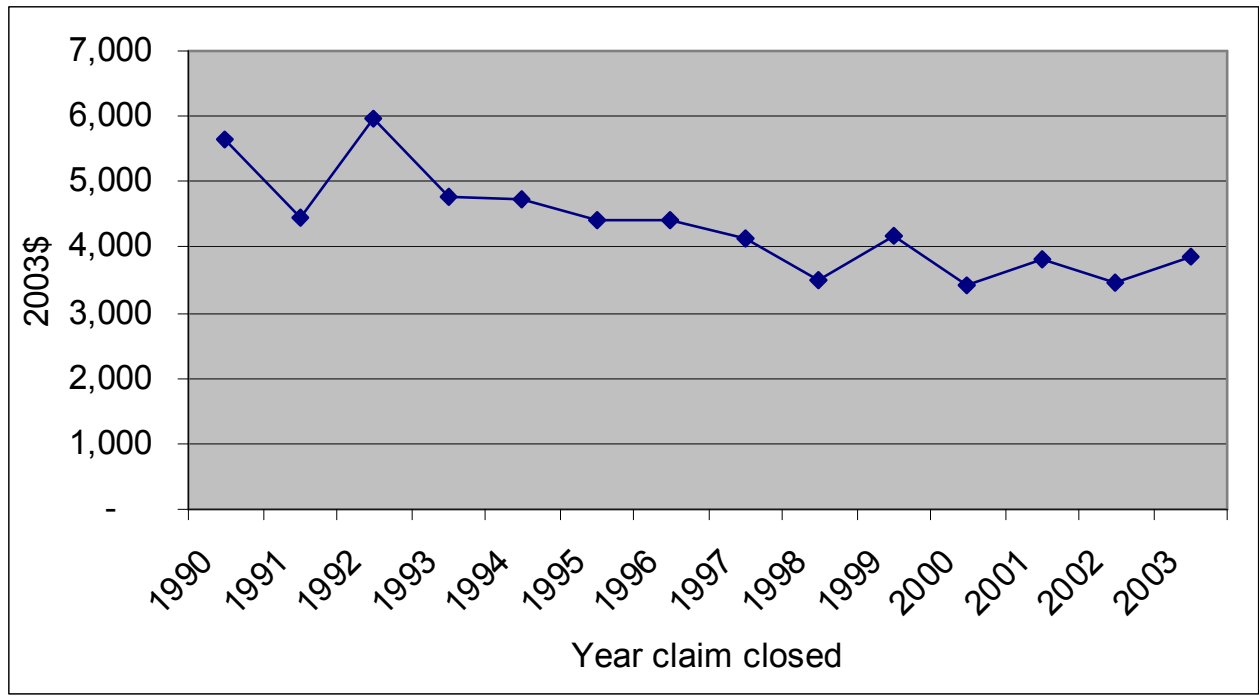

Note: Average total payment per non-federal physician in active practice in Texas (measured in 2003dollars) by year claim closed using all claims against physicians included in the NAR data set of medical malpractice claims closed from 1990-2003 with a payout greater than $\$ 25,000$ in 1988 dollars (including duplicates).

\footnotetext{
${ }^{42}$ Using only perinatal claims, an OLS regression of annual mean payment against year estimates an average annual decrease of $\$ 10,500$ per year $(95 \% \mathrm{CI}=[1,400,19,500])$. An OLS regression of annual median payment against year estimates a average annual decrease of $\$ 4,000$ per year $(95 \%$ $\mathrm{CI}=[1,600,6,500])$.

${ }^{43}$ We obtained the annual number of non-federal physicians in active practice in Texas from the Texas Department of State Health Services, Center for Health Statistics, http://www.dshs.state.tx.us/chs/hpre/PHYS-lnk.shtm.
} 


\section{DISCUSSION}

Our results do not support the conventional wisdom that physicians carry $\$ 1$ million in coverage. For Texas physicians with paid claims, the median real policy had $\$ 500,000$ limits. In some years, the median real policy for perinatal physicians was $\$ 200,000$. If representative, these findings have several implications. First, given the rarity with which payments exceed primary limits, this result implies that less compensation is available to injured patients through the tort system than is conventionally believed. Second, empirical studies that fail to address policy size may generate findings that are suspect. For example, the Medical Liability Monitor (MLM), a widely used source of data, provides pricing information for $\$ 1$ million primary policies. ${ }^{44}$ If many or most doctors carry policies with different limits, MLM-based studies may mischaracterize trends in insurance pricing. Studies that use aggregate premiums collected by state might also misestimate price trends by failing to control for changes in the composition of policies purchased. $^{45}$ Third, some formulas that regulate physician compensation assume that doctors pay for policies providing $\$ 1$ million in liability coverage. ${ }^{46}$ These formulas may be inaccurate and in need of change.

We have not studied the factors that drive policy size or that account for the $31 \%$ (30\%) decline in real mean (median) policies purchased from 1988 to 1999. One possibility is that many doctors purchase the minimum amount of coverage needed to

\footnotetext{
${ }^{44}$ See e.g., Danzon (2004, p. 59) (describing the Medical Liability Monitor data set); General Accounting Office (2003b) (claiming that "[ $\mathrm{t}]$ he most common policies sold by insurers provide $\$ 1$ million of coverage per incident and \$3 million of total coverage per year," and using MLM data to study the relationship between premiums and tort reform).

${ }^{45}$ See e.g., Viscusi and Born (1995) (using total premiums earned aggregated at the state and firm level to estimate the influence of reforms on premiums).

46 AMA, Medicare Resource Based Liability Insurance, http://www.amaassn.org/ama/upload/mm/363/pliwhitepaper.pdf
} 
obtain hospital privileges. Unless these minimums rise with inflation, real policy size will degrade. Another possibility is that competition from surgical centers and office-based surgery has discouraged hospitals from raising their minimum insurance requirements to keep up with inflation. In some cases, hospitals might shoulder a greater share of the liability burden themselves to attract and retain physicians, thus making it easier for physicians to purchase smaller policies. ${ }^{47} \mathrm{We}$ cannot test these theories with our data. We note, however, that we do not observe changes over time in either the number of singledefendant claims or the number of claims with hospitals as co-defendants.

Other explanations for the decline are possible. Texas physicians may have purchased less real coverage on average because: (1) liability risks declined or stabilized owing to tort reforms or other causes; (2) premiums increased; (3) other forms of asset protection were introduced or became less expensive relative to insurance; (4) insurers refused to sell physicians more coverage; or (5) doctors (and/or insurers) increasingly realized that even low-limits policies provide sufficient protection against out-of-pocket risks. Further research is needed to test these hypotheses.

The decline in real policy size coincided with an increase in the tendency of perinatal claims to stack up at the policy limits. This is consistent with infants' damages becoming more likely to equal or exceed physicians' insurance coverage over time. Indeed, this could hardly be otherwise. Future medical costs are a principal component of large awards in "bad baby" cases, and these costs rose dramatically over the period we studied (Levit (2000)). While this seems to be a straightforward explanation for the

\footnotetext{
${ }^{47}$ See e.g., Coleman et al. (1999) (discussing the American Academy of Cosmetic Surgery 1996 Member Survey finding that the majority of cosmetic surgery in the U.S. is performed in the office setting or in ambulatory surgery centers).
} 
increasing tendency of perinatal claims to stack up at or near the policy limits, the stability of spikes at the limits in non-perinatal cases remains a puzzle.

The spike in resolutions at the policy limits is a visual indication that the costs of malpractice claims are concentrated in primary insurers' hands, and that limits often act as a de facto cap on recoveries. Several factors may contribute to the height of the spike. First, plaintiffs may settle for available insurance money rather than bear the cost of obtaining and enforcing above-limit judgments. Litigating to finality means bearing risks and costs as well as considerable delay, during which time the insurance company holds onto funds it would give to the claimant in return for a release of its insured. Second, once settlement negotiations reach the point at which an insurer offers the policy limits, further litigation may be pointless. Many doctors have limited wealth, enjoy the benefit of favorable debtor protection laws (Texas is notable in this regard), or use asset protection strategies to insulate their wealth (Gilles (2006), Stark and Gilman (2005), Lowes (2003). One cannot squeeze blood from a stone (Baker (2001)). Third, professional norms may discourage plaintiffs' attorneys from going after doctors' personal assets. In interviews, litigators report that attacks on defendants' personal assets occur mainly when defendants commit especially heinous acts or intentionally underinsure (Baker (2001)). When we presented our early findings to a group that included Texas lawyers who represent plaintiffs in medical malpractice case, they told us they rarely consider attempting to collect from physicians, and do not consider it worthwhile even to evaluate physicians' net worth to determine if a particular physician might have assets worth pursuing. 
The at-limits spike may understate the number of meritorious cases with actual damages equal to or in excess of limits. In some cases plaintiffs have an incentive to settle for less than the limits even when actual damages equal or exceed the policy limits. For example, an insurer obligated to provide $\$ 1$ million in coverage might offer a plaintiff with a meritorious claim a choice between $\$ 900,000$ today and $\$ 1$ million after a costly trial and possible appeal, which might greatly delay claim resolution.

Although the spike at the policy limits certainly reflects reduced payments on meritorious claims with damages exceeding the limits, pressure from below may influence the size of the spike as well. Hoping to limit their personal exposure, physicians may pressure insurers to pay the limits on claims for which limits exceed expected damages. Insurers may also pay the limits to avoid future litigation costs, for which insurers are wholly responsible.

Neither the spike in settlements at or near the policy limits nor the decline in real policy size necessarily implies that physicians under-insure, whether for purposes of deterrence, compensation, or protection from liability risks. Such an inference would require a theory of optimal insurance purchasing or of optimal compensation for malpractice victims. No such theory has been developed here or elsewhere to our knowledge.

Physician out-of-pocket payments were uncommon. This was true even when physicians carried small policies with limits of $\$ 250,000$ (real) or less. These payments were especially rare when policy size equaled or exceeded $\$ 500,000$ (real). The experience of Texas physicians is consistent with previous findings and anecdotal 
evidence. A 1989 survey of 739 New York physicians sued for medical malpractice found that few made out-of-pocket payments (Lawthers (1992)).

Although some out-of-pocket payments were large, few were catastrophic. Defining “disaster" as an out-of-pocket payment exceeding \$200,000 (2003\$), it struck 17 times in 14 years. On average, 0.043 disasters occurred per 1,000 practicing Texas physicians per year. Over our study period, 7 claims against policies of $\$ 1$ million or more involved physician out-of-pocket payments exceeding \$200,000 (2003\$).

Disasters were rare even in tried cases that yielded large verdicts. Doctors made out-of-pocket payments in only 1 of the 31 cases with verdict-to-limit ratios of 5 or higher (Table 6) and in only 1 of the 20 cases with verdicts above $\$ 5$ million (real). Plaintiff verdicts made out-of-pocket payments more likely, but verdicts tended to be discounted heavily in settlement: the larger the verdict, the steeper the discount. ${ }^{48}$ In addition, insurers paid amounts in excess of the limits more often than physicians did, perhaps to avoid future defense costs or bad-faith-refusal-to-settle claims, which physicians can bring if the verdict exceeds the plaintiff's final offer.

The spike in payments at the policy limits suggests that the low frequency of outof-pocket payments reflects something other than a tendency of physicians to over-insure or to take excessive precautions. The large spikes and payments in jury verdict cases both suggest that even when damages are large relative to policy size plaintiffs rarely collect from physicians' personal assets. This, in turn, suggests limits on the extent to which personal exposure generates deterrence. Of course, if physicians over-estimate their personal exposure or are highly risk averse, even a remote change in personal exposure

\footnotetext{
${ }^{48}$ See Hyman et al. (2007) for analysis of the relationship between jury verdicts and subsequent recoveries by plaintiffs.
} 
could have a substantial deterrent effect. Some studies suggest that physicians substantially over-estimate litigation risk (e.g., Lawthers et al. (1994)).

The direct costs of malpractice judgments and settlements of insured physicians fall mainly on primary insurers and secondarily on excess carriers. Although most legislatures have shied away from capping economic damages, insurance policy limits appear to be an important source of soft caps on malpractice plaintiffs' total recoveries. Plaintiffs with strong, large claims can reasonably expect to recover their damages up to physicians' policy limits, but they are unlikely to receive more. This is true even when plaintiffs prevail in front of juries (Hyman et al., 2007).

\section{CONCLUSION}

This study is the first to quantify the size of physicians' insurance policies, the relationship between policy limits and recoveries, and the extent to which policies of different sizes protect physicians from out-of-pocket payments. Although further study is needed, our results cast doubt on the common assumption that primary professional liability policies with $\$ 1$ million limits predominate. Among Texas physicians with paid claims, smaller policies were more common, and real policy limit size declined substantially over the time period we study (1988-1999). We also find that the frequency of out-of-pocket payments was low across all policy sizes, but rose as policy size declined. Finally, we find that payments at or near the policy limits were common, especially when policies were small, and that payments above the limits from all sources are rare. Even patients with strong claims, such as those who win at trial, must often be satisfied with physicians' primary policy limits, even when this amount only partially compensates the patient's damages. 


\section{References}

American College of Emergency Physicians. 2004. Medical Professional Liability Insurance. http://www.acep.org/NR/rdonlyres/DD94E243-339F-4A02-983D7563D42BCE74/0/MPLIpaperApril04.pdf.

American Medical Association. Liability Insurance Requirements, http://www.amaassn.org/ama/pub/category/4544.html.

Avraham, Ronen. 2006. Database of State Tort Law Reforms. Research Paper No. 902711. Northwestern Law School, Law \& Economics, Evanston, Illinois.

Baker, Tom. 2001. Blood Money, New Money and the Moral Economy of Tort Law in Action. Law \& Society Review 35:275.

Baker, Tom. 2005. Reconsidering the Harvard Medical Practice Study Conclusions about the Validity of Medical Malpractice Claims. Journal of Law, Medicine and Ethics 33:501.

Black, Bernard, Charles Silver, David A. Hyman, and William M. Sage. 2005. Stability, Not Crisis: Medical Malpractice Claim Outcomes in Texas, 1988-2002. Journal of Empirical Legal Studies 2(2):207-59.

Black, Bernard, David A. Hyman, Charles Silver, and William M. Sage. 2007. The Cost of Litigating Medical Malpractice and Other Personal Injury Cases: Evidence from Texas, 1988-2004. Working paper.

Brennan, Troyen A., L.L. Leape, N.M. Laird, L. Hebert, A.R. Localio, A.G. Lawthers, J.P. Newhouse, P.C. Weiler, and H.H. Hiatt. 1991. Incidence of Adverse Events and Negligence in Hospitalized Patients: Results of the Harvard Medical Practice Study I. New England Journal of Medicine 324:370-6.

Brennan, Troyen A., and Michelle M. Mello. 2003. Patient Safety and Medical Malpractice: A Case Study. Annals of Internal Medicine 139:267-273.

Cheney, Frederick W. 1999. How Much Professional Liability Coverage Is Enough? Lessons From the ASA Closed Claims Project. American Society of Anesthesiologists Newsletter 63:6. http://www.asahq.org/Newsletters/1999/06_99/How_0699.html.

Cohen, Thomas H. 2004. Medical Malpractice Trials and Verdicts in Large Counties, 2001. U.S. Department of Justice, Bureau of Justice Statistics. http://www.ojp.usdoj.gov/bjs/pub/pdf/mmtvlc01.pdf.

Coleman III, W.P. 1999. Does the Location of the Surgery or the Specialty of the Physician Affect Malpractice Claims in Liposuction. Dermatologic Surgery 25:343-47. 
Conrad D.A., C. Whitney, P. Milgrom, D. O'Hara, R. Ammons, L. Fiset, W. Vesneski. 1995. Malpractice premiums in 1992: results of a national survey of dentists. Journal of the American Dental Association 126:1045-56.

Cuzick, Jack. 1985. A Wilcoxon-Type Test for Trend. Statistics in Medicine 4:87-89.

Daniels, Stephen, and JoAnne Martin. 2002. It was the Best of Times, It was the Worst of Times: The Precarious Nature of Plaintiff's Practice in Texas. Texas Law Review 80:1781-1828.

Danzon, Patricia M., Andrew J. Epstein and Scott J. Johnson. 2004. The Crisis in Medical Malpractice Insurance. Brookings-Wharton Papers on Financial Services 2004: $55-96$.

General Accounting Office. 1992. Practitioner Data Bank: Information on Small Medical Malpractice Payments (GAO/IMTEC-92-58).

General Accounting Office. 2003a. Medical Malpractice Insurance: Multiple Factors Have Contributed to Premium Rate (GAO-03-702).

General Accounting Office. 2003b. Medical Malpractice and Access to Health Care (GAO-03-836).

Gilles, Stephen G. 2006. The Judgment-Proof Society. Washington and Lee Law Review 63:603-715.

Hyman, David A., Bernard Black, Kathryn Zeiler, Charles Silver, William Sage. 2007. Do Defendants Pay What Juries Award? Post-Verdict Haircuts in Texas Medical Malpractice Cases, 1988-2003. Journal of Empirical Legal Studies 4(1):3-68.

Jenkins, J. 2003. Finding the Truth: The medical malpractice crisis in North Carolina. North Carolina Medical Journal 64:169-175.

Lawthers, Ann G., Russell A. Localio, N.M. Laird, S. Lipsitz , L. Hebert, and Troyen A. Brennan. 1992. Physicians' Perceptions of the Risk of Being Sued. Journal of Health Politics, Policy and Law 17:463-82.

Levit, Katharine, Cynthia Smith, Cathy Cowan, Helen Lazenby and Anne Martin. 2000. Inflation Spurs Health Spending in 2000. Health Affairs 21(1): 172-81.

Lowes, Robert. 2003. Protect your assets before you're sued. Medical Economics 80(4):80-82.

Milgrom PM, L. Fiset, C. Whitney, D. Conrad, T. Cullen, D. O'Hara. 1994. Malpractice claims during 1988-1992: a national survey of dentists. Journal of the American Dental Association 125:462-9. 
Milgrom, P.M., C. Whitney, D. Conrad, L. Fiset, D. O'Hara. 1995. Tort Reform and Malpractice Liability Insurance. Med Care 33:755-64.

National Health Expenditure Data. 2006. Health Expenditures by State, Centers for Medicare and Medicaid Services, Office of the Actuary, National Health Statistics Group. http://www.cms.hhs.gov/NationalHealthExpendData/05_NationalHealthAccountsStateHe althAccounts.asp\#TopOfPage.

O'Hara D.J., D.A. Conrad, P. Milgrom, L. Fiset, C. Whitney. 1994. Dental malpractice liability insurance market: surveys of insurers and insurance commissioners. Journal of the American Dental Association 125:1385-90.

Quinn, Robert. 1998. Medical Malpractice Insurance: The Reputation Effect and Defensive Medicine. Journal of Risk and Insurance 65(3):467-84.

Rice, Berkeley. 2003. Could a malpractice mega-verdict wipe you out? Medical Economics 80(10): 80-89.

Silver, Charles. 2002. Does Civil Justice Cost Too Much? Texas Law Review 80:20732113.

Stark, B. and P.A. Gilman. 2005. Basics of asset protection. Journal of Medical Practice Management 20:207-209.

Studdert, David M., Eric J. Thomas, Helen R. Burstin, Brett I.W. Zbar, John E. Orav, and Troyen A. Brennan. 2000. Negligent Care and Malpractice Claiming Behavior in Utah and Colorado. Medical Care 38(3):250-60.

Studdert, David M., Y. Tony Tang, and Michelle M. Mello. 2004. Are Damages Caps Regressive?: A Study of Malpractice Jury Verdicts in California. Health Affairs 23(4):5467.

Texas Department of Health, Center for Health Statistics -DDM. 2001. Cooperative Annual Survey of Hospitals 12 (March 2003).

Texas Department of Health, Center for Health Statistics. 2003. Supply Trends Among Licensed Health Professions: Texas, 1980-2002. http://www.dshs.state.tx.us/chs/hprc/trendrpt.pdf

Texas Department of Insurance. 2003. Medical Malpractice Insurance: Overview and Discussion. http://www.tdi.state.tx.us/general/pdf/spromptpay.pdf.

Texas Department of State Health Services, Center for Health Statistics. 2006. County Supply and Distribution Tables. http://www.dshs.state.tx.us/chs/hprc/PHYS-lnk.shtm (last updated November 26, 2006). 
Thomas, Eric J., David M. Studdert, Joseph P. Newhouse, Brett I.W. Zbar, K. Mason Howard, Elliot J. Williams, and Troyen A. Brennan. 1999. Costs of Medical Injuries in Utah and Colorado. Inquiry 36(3):255-64.

Thomas, Eric J., David M. Studdert, Helen R. Burstin, John E. Orav, Timothy Zeena, Elliot J. Williams, K. Mason Howard, Paul C. Weiler, and Troyen A. Brennan. 2000. Incidence and Types of Adverse Events and Negligent Care in Utah and Colorado. Medical Care 38(3):261-71.

U.S. Department of Health and Human Services. 2006. National Health Expenditure Data, Health Expenditures by State, Centers for Medicare and Medicaid Services. http://www.cms.hhs.gov/NationalHealthExpendData/05_NationalHealthAccountsStateHe althAccounts.asp\#TopOfPage.

Viscusi, W. Kip and Patricia Born. 1995. Medical Malpractice Insurance in the Wake of Liability Reform. Journal of Legal Studies 24(2):463-90. 


\section{Appendix: Various data sources}

\begin{tabular}{|l|l|l|}
\hline \multicolumn{1}{|c|}{ Variable } & \multicolumn{1}{|c|}{ Source } & \multicolumn{1}{c|}{ Application } \\
\hline Real Dollars & $\begin{array}{l}\text { Consumer Price Index for All Urban } \\
\text { Consumers. U.S. Department of Labor, } \\
\text { Bureau of Labor Statistics } \\
\text { http://www.bls.gov/cpi/home.htm\#tables } \\
\text { (using the average consumer price index } \\
\text { each calendar year for changes in prices of } \\
\text { all goods and services purchased for } \\
\text { consumption by urban households) }\end{array}$ & $\begin{array}{l}\text { Used as an index to convert } \\
\text { nominal dollars to real } \\
\text { dollars for indicated base } \\
\text { year, usually 2003. }\end{array}$ \\
\hline $\begin{array}{l}\text { Texas } \\
\text { Population }\end{array}$ & $\begin{array}{l}\text { Population Division, U.S. Census Bureau; } \\
\text { http://www.census.gov/popest/states/. }\end{array}$ & $\begin{array}{l}\text { Used as an index to } \\
\text { normalize other variables for } \\
\text { population growth, as a } \\
\text { proxy for health care } \\
\text { consumption. }\end{array}$ \\
\hline $\begin{array}{l}\text { Texas } \\
\text { Physicians }\end{array}$ & $\begin{array}{l}\text { Nonfederal physicians in active practice in } \\
\text { Texas (1991 estimated). Texas Department of } \\
\text { State Health Services, Center for Health } \\
\text { Statistics, } \\
\text { http://www.dshs.state.tx.us/chs/hprc/PHYS- } \\
\text { lnk.shtm. }\end{array}$ & $\begin{array}{l}\text { Used to adjust other } \\
\text { variables for growth of } \\
\text { physician supply, as a proxy } \\
\text { for health care consumption. }\end{array}$ \\
\hline $\begin{array}{l}\text { Texas Department of State Health Services, } \\
\text { County Supply and Distribution Tables. } \\
\text { http://www.dshs.state.tx.us/chs/hprc/PHYS- } \\
\text { lnk.shtm }\end{array}$ & $\begin{array}{l}\text { Used to adjust other } \\
\text { variables for growth of } \\
\text { provision of medical } \\
\text { services, as a proxy for } \\
\text { health care consumption. }\end{array}$ \\
\hline
\end{tabular}

